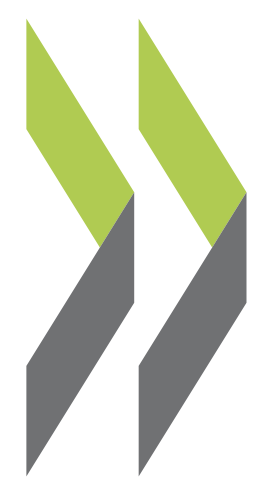

OECD Economics Department Working Papers No. 1163

Reducing the High Rate of Poverty Among
the Elderly in Korea Randall S. Jones, Satoshi Urasawa 
Organisation de Coopération et de Développement Économiques

Organisation for Economic Co-operation and Development

16-Sep-2014

ECONOMICS DEPARTMENT

English - Or. English

\section{REDUCING THE HIGH RATE OF POVERTY AMONG THE ELDERLY IN KOREA}

ECONOMICS DEPARTMENT WORKING PAPERS No. 1163

By Randall S. Jones and Satoshi Urasawa

OECD Working Papers should not be reported as representing the official views of the OECD or of its member countries. The opinions expressed and arguments employed are those of the author(s).

Authorised for publication by Alvaro Pereira, Director, Country Studies Branch, Economics Department.

All Economics Department Working Papers are available through OECD's Internet website at http://www.oecd.org/eco/workingpapers.

JT03362022

Complete document available on OLIS in its original format

This document and any map included herein are without prejudice to the status of or sovereignty over any territory, to the delimitation of international frontiers and boundaries and to the name of any territory, city or area. 
OECD Working Papers should not be reported as representing the official views of the OECD or of its member countries. The opinions expressed and arguments employed are those of the author(s).

Working Papers describe preliminary results or research in progress by the author(s) and are published to stimulate discussion on a broad range of issues on which the OECD works.

Comments on Working Papers are welcomed, and may be sent to the Economics Department, OECD, 2 rue André-Pascal, 75775 Paris Cedex 16, France, or by e-mail to eco.contact@oecd.org.

This document and any map included herein are without prejudice to the status of or sovereignty over any territory, to the delimitation of international frontiers and boundaries and to the name of any territory, city or area.

The statistical data for Israel are supplied by and under the responsibility of the relevant Israeli authorities. The use of such data by the OECD is without prejudice to the status of the Golan Heights, East Jerusalem and Israeli settlements in the West Bank under the terms of international law.

\section{(C) OECD (2014)}

You can copy, download or print OECD content for your own use, and you can include excerpts from OECD publications, databases and multimedia products in your own documents, presentations, blogs, websites and teaching materials, provided that suitable acknowledgment of OECD as source and copyright owner is given. All requests for commercial use and translation rights should be submitted to rights@oecd.org 


\section{ABSTRACT/RÉSUMÉ \\ Reducing the high rate of poverty among the elderly in Korea}

One-half of Korea's population aged 65 and over lives in relative poverty, nearly four times higher than the OECD average of $13 \%$. Elderly poverty is thus an urgent social problem. The immediate priority is to target the Basic Old-Age Pension on the lowest-income elderly to ensure that they escape from absolute poverty. The Basic Livelihood Security Programme should be used to top up the income of poor elderly by further relaxing eligibility requirements. In addition, reforms are needed to develop an effective three-pillar system of retirement income based on the National Pension Scheme (NPS), company pensions and individual savings. Making the NPS more effective in reducing elderly poverty requires expanding its coverage, focusing on improved compliance among non-regular and self-employed workers, lengthening average contribution periods and maintaining the NPS replacement at around 50\%, keeping it close to the OECD average. The increase in the contribution rate should begin as soon as possible, as delays would only make the necessary increase larger.

This Working Paper relates to the 2014 OECD Economic Survey of Korea (www.oecd.org/eco/surveys/economic-survey-korea.htm)

JEL classification: H55, J26.

Keywords: elderly poverty, National Pension Scheme, National Pension Fund, Basic Livelihood Security Programme, Basic Old-Age Pension, company pensions, occupational pensions, retirement allowance, individual pension accounts, replacement rate, population ageing.

\section{Réduire le taux de pauvreté élevé des personnes âgées en Corée}

La moitié de la population âgée de 65 ans et plus est en situation de pauvreté relative, ce qui est près de quatre fois plus élevé que la moyenne de $13 \%$ constatée à l'échelle de l'OCDE. La pauvreté chez les personnes âgées constitue donc un problème de société urgent. La priorité immédiate est de cibler le minimum vieillesse sur les personnes âgées les plus démunies, pour éviter qu'elles ne tombent dans la pauvreté absolue. Le Programme de garantie du minimum de subsistance doit servir à compléter le revenu des personnes âgées pauvres en assouplissant davantage les conditions d'admissibilité. En outre, des réformes sont nécessaires pour mettre en place un régime de retraite à trois piliers : régime national de retraite (RNR), retraites d'entreprise et épargne individuelle. Pour rendre le RNR plus efficace dans la réduction de la pauvreté des personnes âgées, il faut étendre sa couverture, en se concentrant sur l'amélioration de la conformité chez les travailleurs non réguliers et indépendants, l'allongement de la période de cotisation moyenne et le maintien du taux de remplacement du RNR autour de $50 \%$, proche de la moyenne OCDE. L'augmentation du taux de cotisation devrait débuter le plus tôt possible, tout retard entraînant nécessairement une hausse plus importante.

Ce Document de travail a trait à l'Étude économique de l'OCDE de la Corée, 2014 (www.oecd.org/fr/eco/etudes/coree.htm).

Classification JEL : H55, J26.

Mots clés : pauvreté chez les plus âgés, régime national de retraite, Fonds national de retraite, Programme de garantie du minimum de subsistance, minimum vieillesse, retraites d'entreprise, indemnité de retraite, épargne individuelle, taux de remplacement, vieillissement de la population. 


\section{TABLE OF CONTENTS}

REDUCING THE HIGH RATE OF POVERTY AMONG THE ELDERLY IN KOREA ......................... 5

Overview of the income support system for Korea's elderly ............................................................... 7

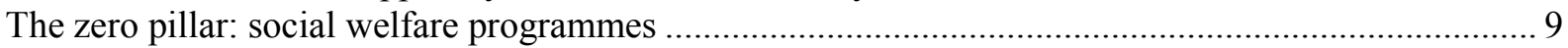

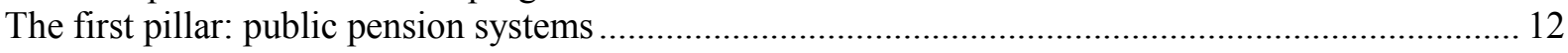

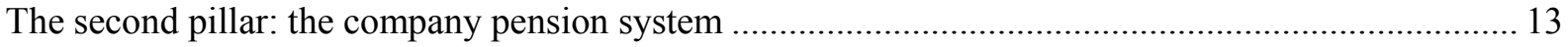

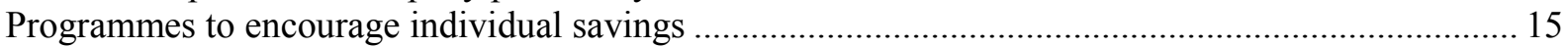

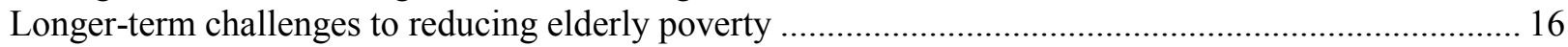

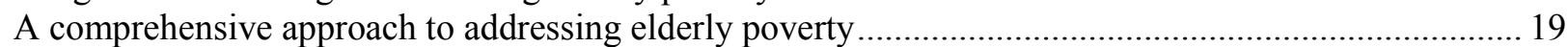

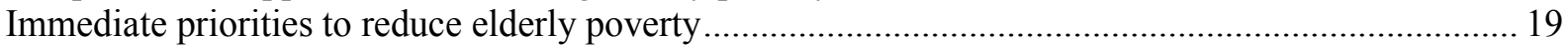

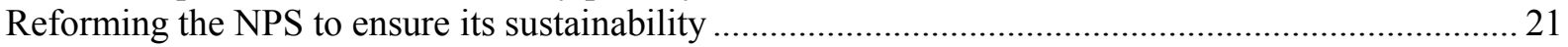

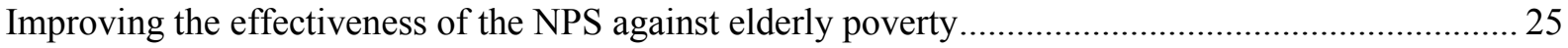

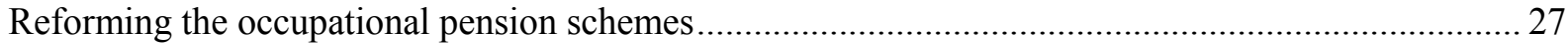

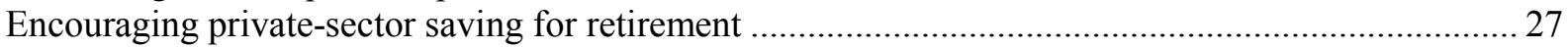

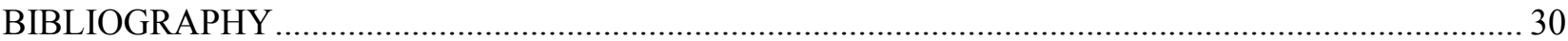

\section{Tables}

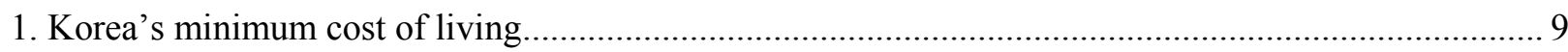

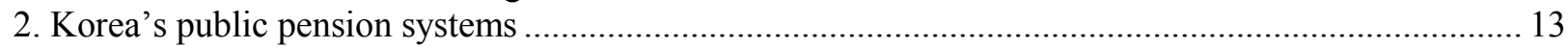

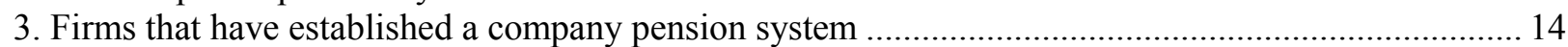

4. The number of employees in company pension systems by type of plan ....................................... 15

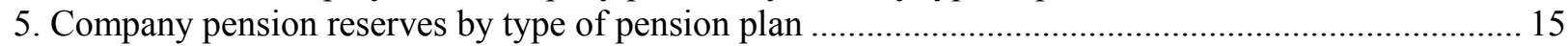

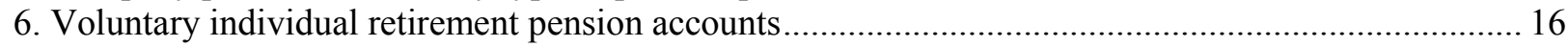

7. Long-term projections of the coverage of the National Pension Scheme .......................................... 17

8. Long-term projections of the financial balance of the National Pension Scheme............................... 18

9. Contribution rates required to accomplish financial goals .............................................................. 23

10. The impact of delaying hikes in the pension contribution rate ....................................................... 24

\section{Figures}

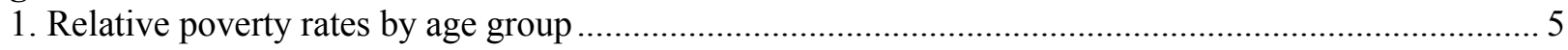

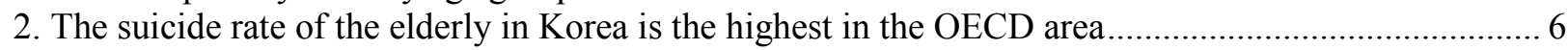

3. Public spending on old-age and survivors benefits in Korea is low................................................ 7

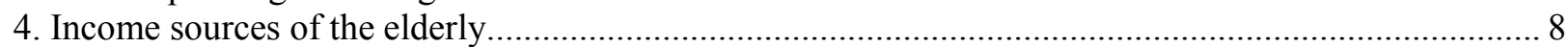

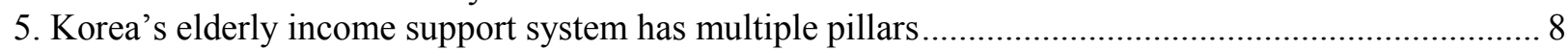

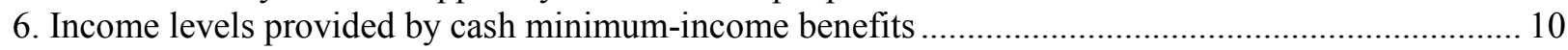

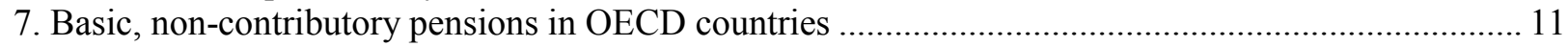

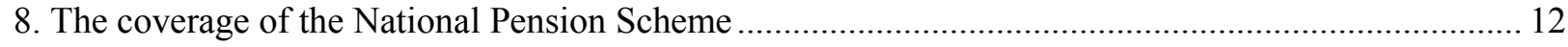

9. Population ageing in Korea is projected to be the fastest in the OECD area ...................................... 17

10. Long-run projections for the National Pension Scheme................................................................ 19

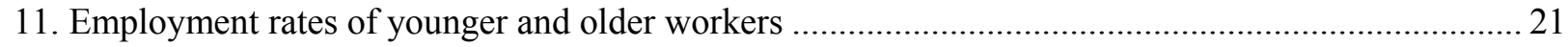

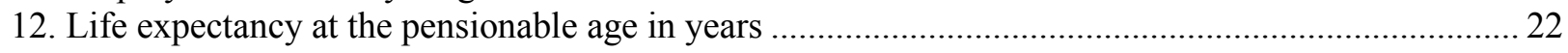

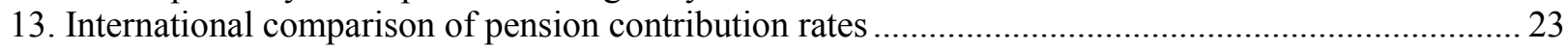

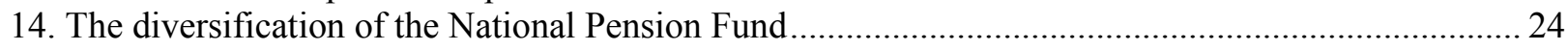

15. An international comparison of pension replacement rates ............................................................. 26

\section{Boxes}

Box 1. Summary of recommendations to address poverty among the elderly in Korea ........ 
ECO/WKP(2014)59

\title{
REDUCING THE HIGH RATE OF POVERTY AMONG THE ELDERLY IN KOREA
}

\author{
Randall S. Jones and Satoshi Urasawa ${ }^{l}$
}

1. Poverty in Korea is concentrated among the elderly. In 2011, 49\% of the population aged 65 and over lived in relative poverty, the highest proportion among OECD countries and nearly four times higher than the OECD average of $13 \%$. Moreover, the gap between the poverty rate of the elderly and that of the total population in Korea is the largest, at more than three times greater than the $15 \%$ rate for the entire population. In contrast, the elderly poverty rate in the OECD area is almost equal to the overall average (Figure 1). The average income of Korea's elderly population was only $61 \%$ of the national average, well below the OECD average of $86 \%$.

Figure 1. Relative poverty rates by age group ${ }^{1}$

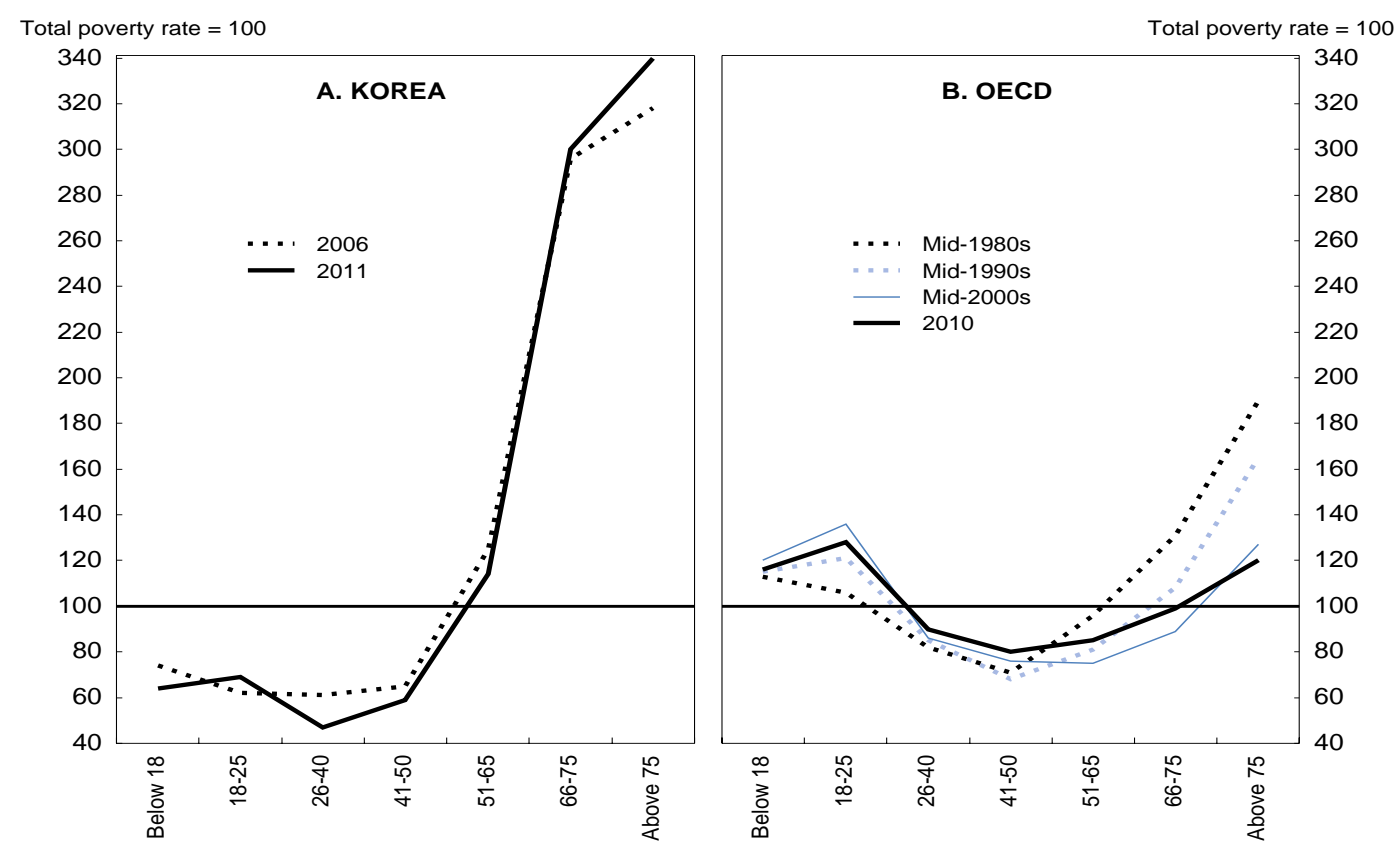

1. The figure shows the poverty rate for each age group using an index, with the rate for the entire population set at 100 . The poverty threshold is set at $50 \%$ of median income of the entire population. The OECD average includes 20 member countries.

Source: OECD Income Distribution Database (www.oecd.org/social/income-distribution-database.htm).

2. The government has no data on the share of elderly in absolute poverty, defined as an income below the minimum cost of living, which is set at $40 \%$ of the national median income. It is likely to be significant, as the share of Korea's population in absolute poverty, at $7-8 \%$, is about half of the $15 \%$ in relative poverty. In $2012,26 \%$ of the elderly has a monthly income below 450 thousand KRW (\$433), well below the minimum cost of living set by the government at 553 thousand KRW (MHW, 2013), which would place them in absolute poverty.

1. Randall S. Jones is head of the Japan/Korea Desk in the Economics Department of the OECD and Satoshi Urasawa is an economist on that Desk. This paper is based on material prepared for the OECD Economic Survey of Korea published in June 2014 under the authority of the Economic and Development Review Committee (EDRC). The author would like to thank Andrew Dean, Robert Ford, Michael Förster, Myungkyoo Kim, Vincent Koen, and Andrew Reilly, as well as officials from the Korean government, for valuable comments on earlier drafts. Special thanks go to Lutécia Daniel for technical assistance and to Nadine Dufour and Mikel Inarritu for technical preparation. 
3. Addressing the high elderly poverty rate is essential to promote social cohesion in Korea. While the suicide rate of young people is close to the OECD average, rising poverty among the elderly contributed to an increase in their suicide rate from 34 (per 100 thousand persons) in 2000 to 72 in 2010 , far above the OECD average of 22 (Figure 2). According to a government survey of elderly who have considered suicide, "economic hardship" is the second-most cited reason, following "disease and disability" (Statistics Korea, 2010). In sum, the generation responsible for Korea's economic miracle has been poorly rewarded.

Figure 2. The suicide rate of the elderly in Korea is the highest in the OECD area

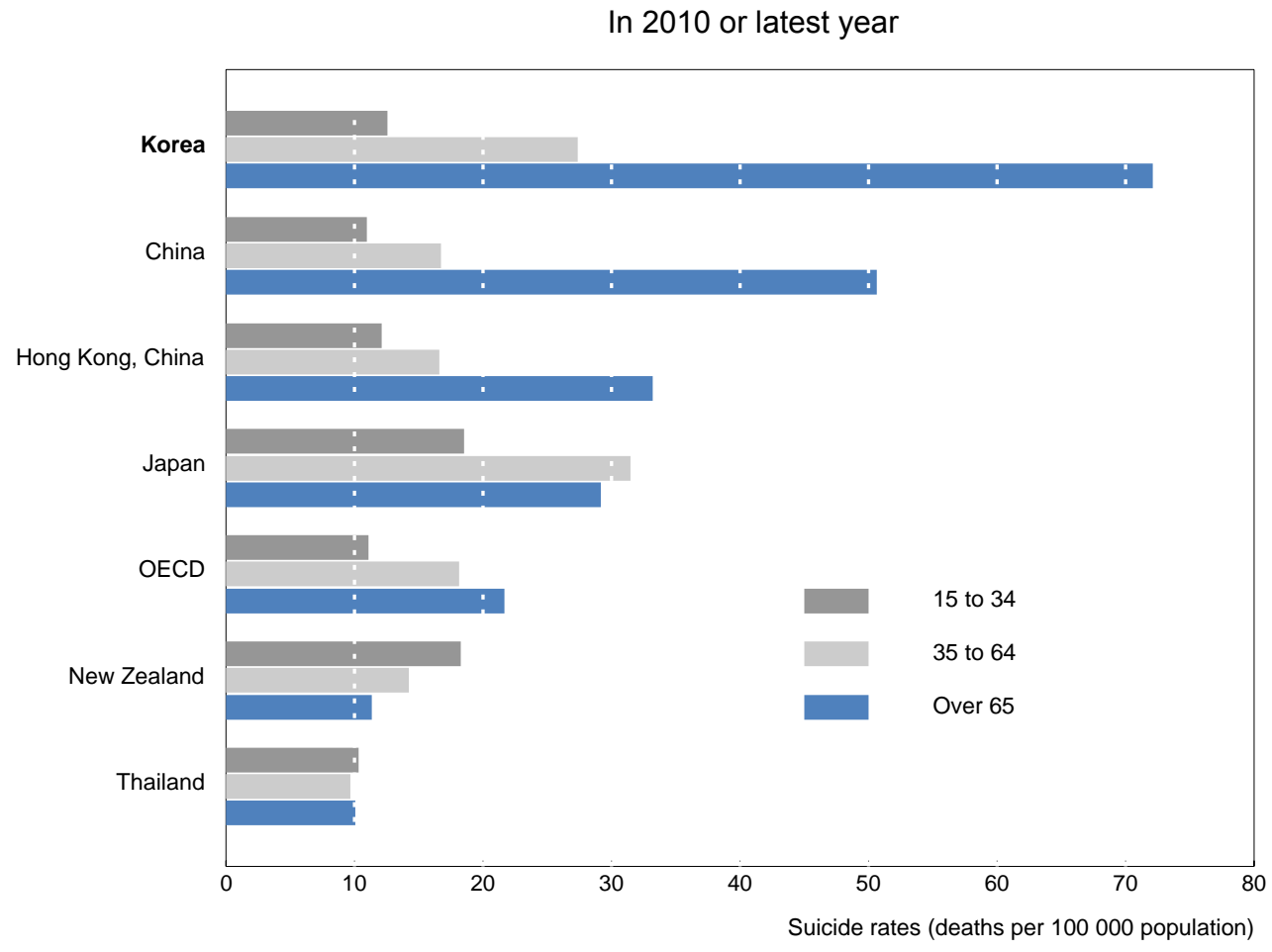

Source: OECD (2011b).

4. The high elderly poverty rate reflects the decline in family support before other private and public sources of old-age income have matured. In contrast to many OECD countries, where population ageing and the development of a public pension systems occurred over a long time span, rapid population ageing in Korea has left it less prepared. Many elderly had assumed that their children would care for them, thus making it unnecessary to prepare financially. Private transfers, including family support, have fallen from 55\% of the elderly's income in 1990 to $45 \%$ in 2008 (Kim, 2013a). The increase in the number of elderly living alone - from 0.54 million in 2000 to 1.25 million (a quarter of the elderly) in 2010 - also indicates declining family support. The share is expected to rise further to $40 \%$ in 2030 (Kim, 2013b). In 2008 , the income of single elderly persons was less than $60 \%$ of that of other elderly, resulting in a poverty rate of $71 \%(\mathrm{OECD}, 2011 \mathrm{a}){ }^{2}$ The rising number of elderly living alone and their increasing rate of poverty reflect a weakening commitment to help older family members.

2. According to the 2011 government survey, total annual income for a household where the elderly lived with their children was 37.63 million KRW (around \$36 000), while the income for a single elderly household was 8.41 million KRW (\$8 100). Assuming that households that include elderly persons living with their children consisted of four adults, its level of income per person would still be $78 \%$ higher than that of the single elderly household using the OECD's income equivalence scale. 
5. The decline in family support has left a void that is only partially filled by other sources of retirement income. Only $29 \%$ of the elderly received old-age pensions from the National Pension Scheme (NPS) in 2012. Moreover, the average NPS old-age benefit was low at around half of the minimum cost of living. With low coverage and benefits, public expenditure on old-age and survivor benefits in Korea amounted to only $2.4 \%$ of GDP in 2009 , the third lowest in the OECD area and well below the OECD average of $8.3 \%$ (Figure 3). Consequently, public transfers, including pensions, accounted for only $16 \%$ of the elderly's income in the mid-2000s compared to the OECD average of 59\% (Figure 4). In addition, the company pension system launched in 2005 is at an early stage of development, with the number receiving benefits accounting for only 3\% of those enrolled in the system. In contrast, labour income provided 58\% of the elderly's income in Korea, the highest in the OECD area.

6. This paper begins with an overview of the income support system for Korea's elderly, including social welfare programmes, public pensions, private pensions and individual savings. After a discussion of the longer-term challenges of addressing elderly poverty, the paper discusses policies options to reduce it. Recommendations are summarised in Box 1.

Figure 3. Public spending on old-age and survivors benefits in Korea is low Social spending by components, in per cent of GDP in 2010

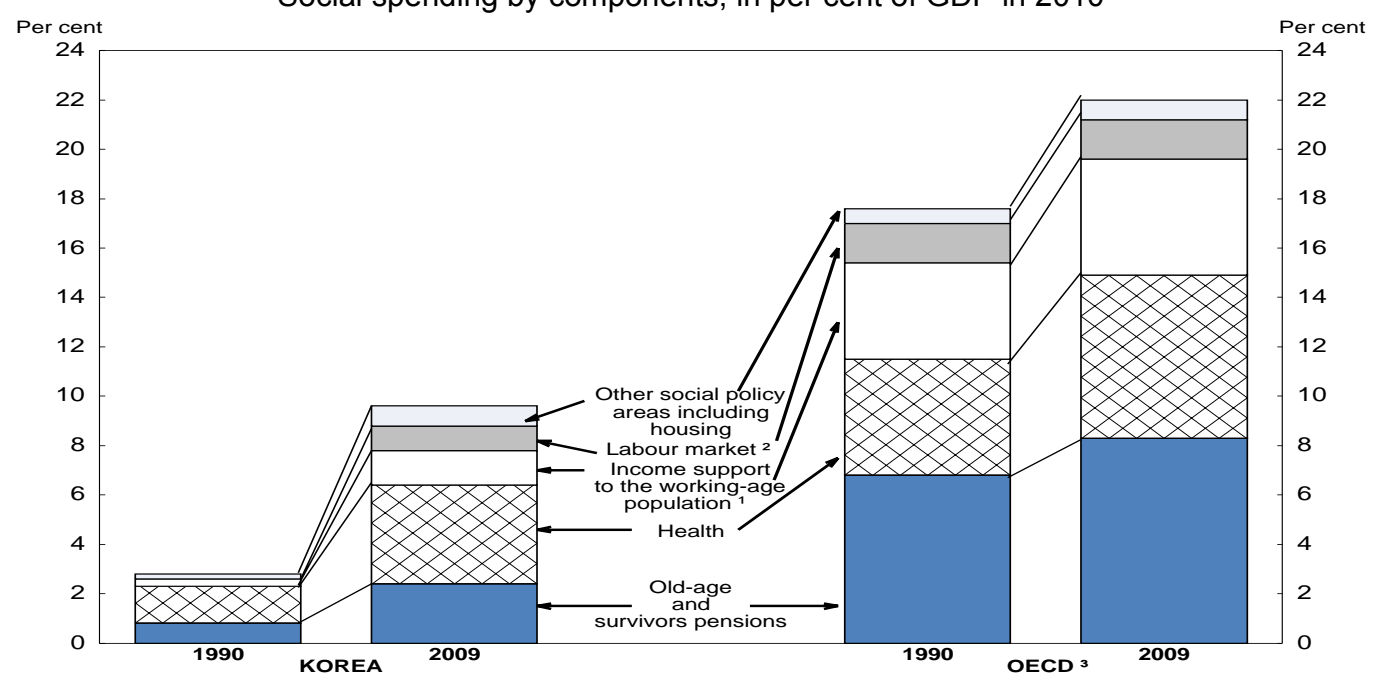

1. Includes the spending categories "Incapacity related" and "Family".

2. Includes the spending categories of "Active labour market programmes" and "Unemployment".

3. Weighted average of 34 OECD countries.

Source: OECD Social Expenditure Database (www.oecd.org/els/social/expenditure).

\section{Overview of the income support system for Korea's elderly}

7. Korea's income support system has developed without an overall systemic plan, leading to vigorous competition among diverse programmes to expand their coverage (Kim, 2013a). The system includes (Figure 5):

- Social welfare: the Basic Livelihood Security Programme (BLSP) and the Basic Old-Age Pension System (BOAP).

- Public pensions: the National Pension Scheme (NPS) and occupational pensions.

- Private savings: the company pension system, and schemes to promote individual savings. 
Korea thus has created a multi-pillar system, although it is insufficient at present to prevent a high poverty rate among the elderly. This system has been supplemented by the introduction of Long-term Care Insurance for the elderly in 2008 and employment programmes for the elderly, including the creation of 230 thousand public-sector jobs for low-income elderly.

Figure 4. Income sources of the elderly In 2008 or latest year

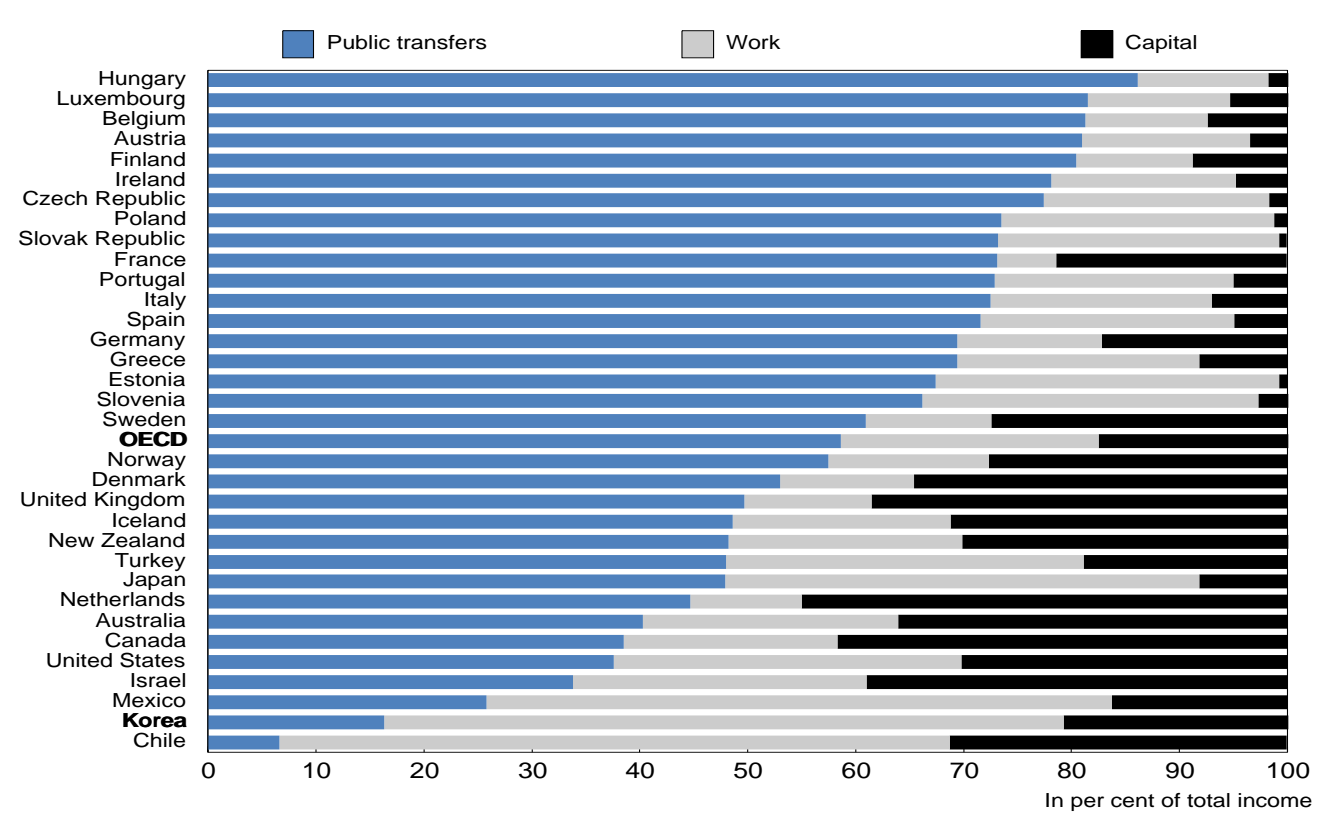

Source: OECD (2013a).

Figure 5. Korea's elderly income support system has multiple pillars

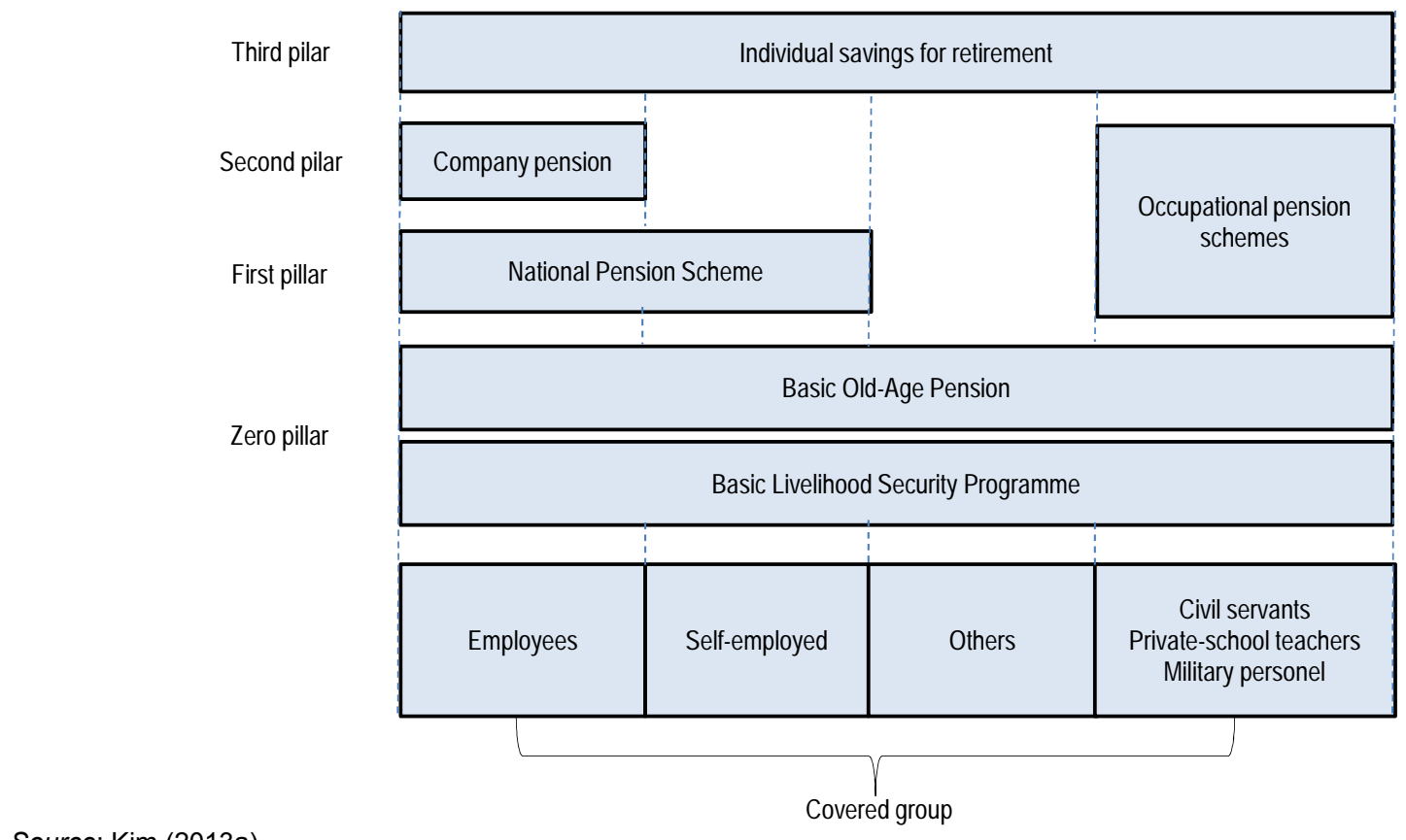

Source: $\operatorname{Kim}(2013 a)$. 


\section{The zero pillar: social welfare programmes}

\section{The Basic Livelihood Security Programme}

8. The BLSP, which was introduced in 2000, provides cash and a package of in-kind benefits, such as housing and education, to eligible persons living in absolute poverty. Absolute poverty is defined as an income below the minimum cost of living (MCL), which the government sets each year at $40 \%$ of the national median income. The BLSP provides a benefit matching the MCL, which is equivalent to around $26 \%$ of the average income (Table 1). Korea is in the bottom third of OECD countries with respect to the cash minimum income benefit as a share of the average income (Figure 6). BLSP benefits were provided to 1.4 million persons ( $2.8 \%$ of the population) in 2011 , with total expenditures of $0.6 \%$ of GDP. The number of BLSP recipients has slightly decreased since then due to the introduction of an integrated information system for better enforcement of the eligibility criteria.

9. However, $7-8 \%$ of the population is in absolute poverty (OECD, 2013b). The failure of the BLSP to lift all those in absolute poverty to an income matching the MCL reflects its limited coverage due to strict eligibility criteria. First, the income criterion includes asset ownership, which is converted into property income. Second, those with the possibility of assistance from family members are not eligible for benefits under the so-called "family support obligation rule". However, many children cannot or will not help their elderly parents. Currently, around 380 thousand elderly, $6.3 \%$ of Korea's over-age 65 population, receive BLSP benefits. The number of recipients is small relative to the 2.3 million elderly in absolute poverty.

Table 1. Korea's minimum cost of living

Thousand KRW per month for a single person

\begin{tabular}{c|ccccc}
\hline Year & $\begin{array}{c}\text { Minimum } \\
\text { cost of living }^{1} \\
(\mathrm{~A})\end{array}$ & $\begin{array}{c}\text { Average }_{\text {wage }^{2}} \\
(\mathrm{~B})\end{array}$ & $\begin{array}{c}\text { Minimum cost of living as } \\
\text { \% of average wage } \\
(\mathrm{A}) /(\mathrm{B})\end{array}$ & $\begin{array}{c}\text { Average } \\
\text { income }^{3} \\
(\mathrm{C})\end{array}$ & $\begin{array}{c}\text { Minimum cost of living } \\
\text { as \% of average income } \\
(\mathrm{A}) /(\mathrm{C})\end{array}$ \\
\hline 2009 & 489 & 2636 & 18.6 & 1810 & 27.0 \\
2010 & 504 & 2806 & 18.0 & 1979 & 25.5 \\
2011 & 532 & 2844 & 18.7 & 2068 & 25.7 \\
2012 & 553 & 2996 & 18.5 & 2121 & 26.1 \\
$2013^{4}$ & 572 & 3080 & 18.6 & 2197 & 26.0 \\
$2014^{4}$ & 603 & 3188 & 18.9 & 2295 & 26.3 \\
\hline
\end{tabular}

1. Based on 11 categories of consumer goods. An income below this level is classified as absolute poverty.

2. All industries.

3. Gross domestic product divided by population. The median income is somewhat lower than the average.

4. OECD projections for average wages and income.

Source: Bank of Korea, Statistics Korea, Ministry of Health and Welfare and OECD estimates.

10. Eligibility criteria for the BLSP are being relaxed:

- The family support obligation rule has been eased since the inception of the BLSP in 2003 to improve its coverage.

- The treatment of assets was relaxed in 2013. The conversion rate for turning house ownership into monthly income was cut from $4.2 \%$ to $1.0 \%$ in 2013 , although it remains high compared to the rates used in some other OECD countries. Around two-thirds of OECD countries disregard the value of a claimant's home in determining eligibility for social benefits.

- The government plans to increase the income criterion for the in-kind benefits, such as for health care and education, from $40 \%$ of median income to between $40 \%$ and $50 \%$ of the national median income. The phased-in withdrawal of the BLSP benefits will reduce poverty traps that discourage 
work. While the subsistence cash benefit will still be limited to those with an income of less than $40 \%$ of the national median, the threshold for the cash benefit for housing will be raised to $43 \%$ of the national median.

Figure 6. Income levels provided by cash minimum-income benefits

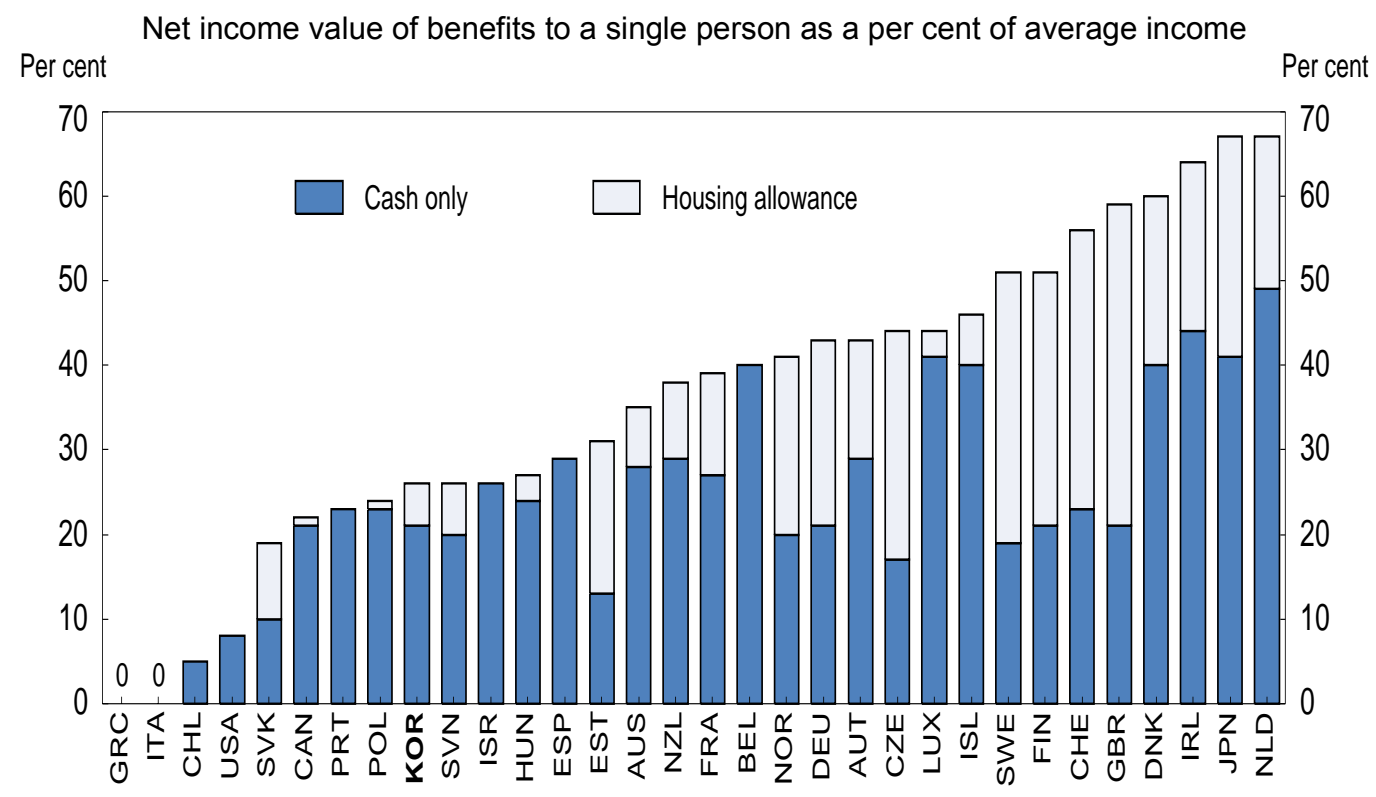

Source: OECD (2013b).

11. Together, these changes are expected to boost the number of BLSP recipients (of all ages) from 1.4 million to 1.8 million. However, even if all of the new recipients were over age 65, the number of elderly receiving the BLSP would remain below 800 thousand, about one-third of the elderly in absolute poverty.

\section{The Basic Old-Age Pension System}

12. The BOAP was introduced in 2008 as a social welfare programme to provide assistance to elderly persons. The benefit was set at $5 \%$ of the average income of persons contributing to the NPS during the preceding three years. In 2012, the benefit reached 97 thousand KRW (around $\$ 93$ or about 3\% of the average wage). It thus amounts to only $16 \%$ of the minimum cost of living. Currently, nearly $67 \%$ of the elderly receive the benefit. The BOAP thus spreads out resources very thinly over a large segment of the older population, doing little to reduce poverty. Most OECD countries provide basic pensions that are larger and more narrowly targeted so as to reduce elderly poverty. In 2011, 31 OECD countries, including Korea, had non-contributory benefits that are means-tested based on the elderly's total income or pension benefit receipts, with an average benefit equal to $31 \%$ of economy-wide average earnings (Figure 7). Korea was the lowest at $3 \%$ of average earnings, while the coverage of the BOAP was exceptionally large compared to an OECD average of $28 \%$ (Panel B).

13. The broad coverage of the BOAP and small benefit seems to have varied from its original purpose. The law establishing the BOAP stated that the objective is to stabilise the livelihood of the elderly and promote their welfare by providing the financially-distressed elderly with the BOAP benefits (Yun, 2013). 
Figure 7. Basic, non-contributory pensions in OECD countries

In 2012
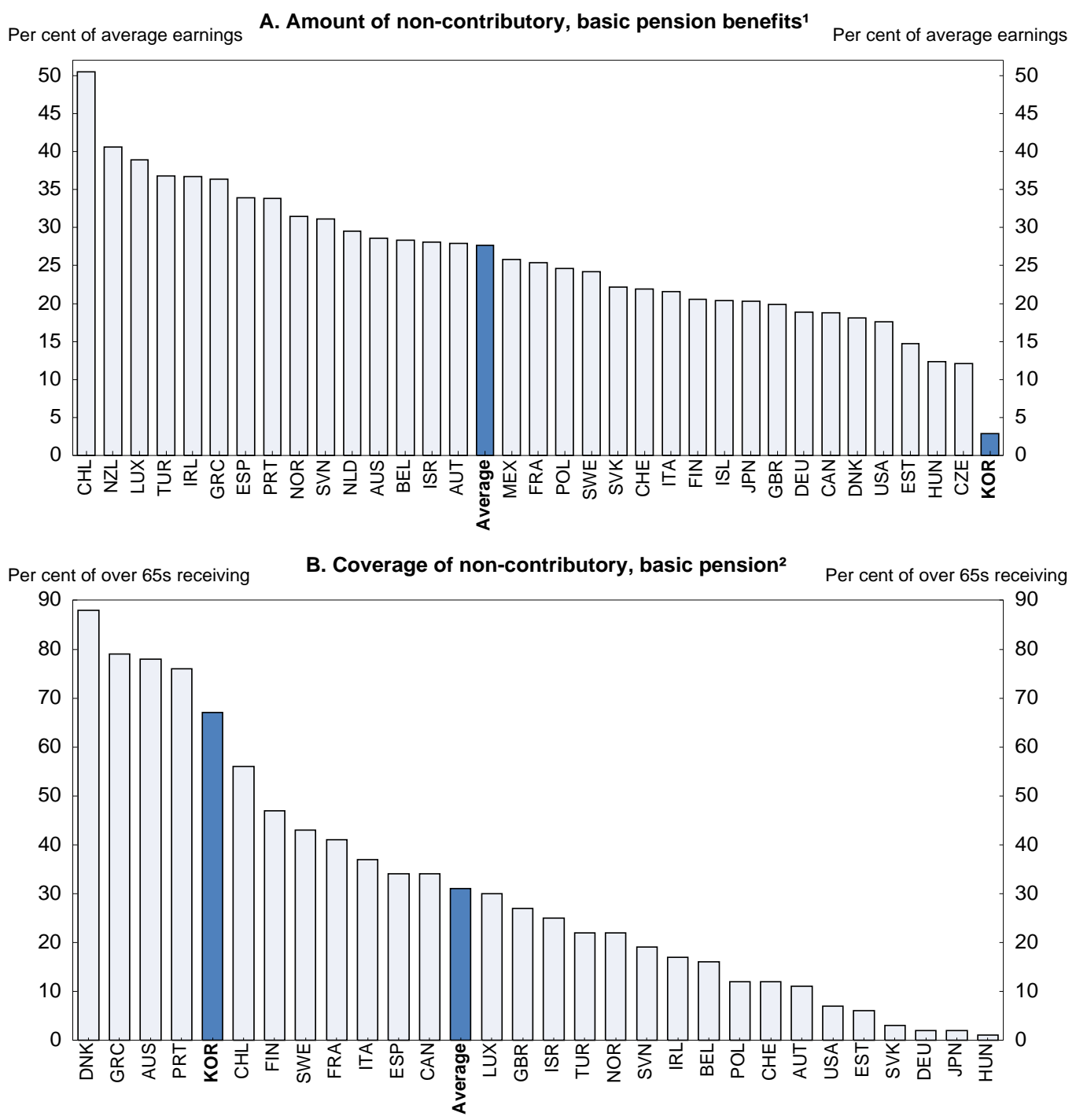

1. As a per cent of economy-wide average earnings.

2. As a per cent of the population aged 65 and over.

Source: OECD (2013a).

14. The government that took office in February 2013 initially promised to provide the BOAP to all persons over age 65 and double it to $10 \%$ of the average income of persons contributing to the NPS during the preceding three years. This proposal would have more than doubled outlays on the BOAP from 27 trillion KRW (2.1\% of 2012 GDP) to 57 trillion KRW between 2014 and 2017. Given its commitment to not raise taxes, the government has scaled back its planned expansion of the BOAP to reduce its cost:

- Seventy per cent of the 6 million elderly will receive the BOAP, around the same share as at present.

- Of the recipients, $60 \%$ will receive the full 200 thousand KRW, while the remainder will get between 100 thousand and 200 thousand KRW depending on their income. 
This proposal, which is to be implemented in July 2014, would raise the cost of the BOAP by about 13 trillion KRW ( $1 \%$ of 2012 GDP) over the four-year period to 40 trillion KRW.

\section{The first pillar: public pension systems}

\section{The National Pension Scheme}

15. The NPS was created in $1988^{3}$ as a partially-funded system with a strong redistributive element. Its coverage was initially limited to regular employees in firms with at least ten workers and then gradually expanded to include all workplaces and types of employees and the self-employed. ${ }^{4}$ Although participation has been mandatory by law since 1999, in practice the NPS still excludes a large number of people in vulnerable groups (Kim, 2013b). The number registered as insured persons reached $55 \%$ of the workingage population in 2012 (NPS, 2012a). However, the number actually contributing to the NPS was much lower at $43 \%$ of the working-age population (Figure 8). The coverage is thus far below the $80-100 \%$ in other advanced countries (Lee, 2012). The low share reflects a lack of trust in the pension system, as well as the large number of self-employed and non-regular workers, who can evade contributions. In addition, some self-employed persons are exempted from paying premiums due to low income.

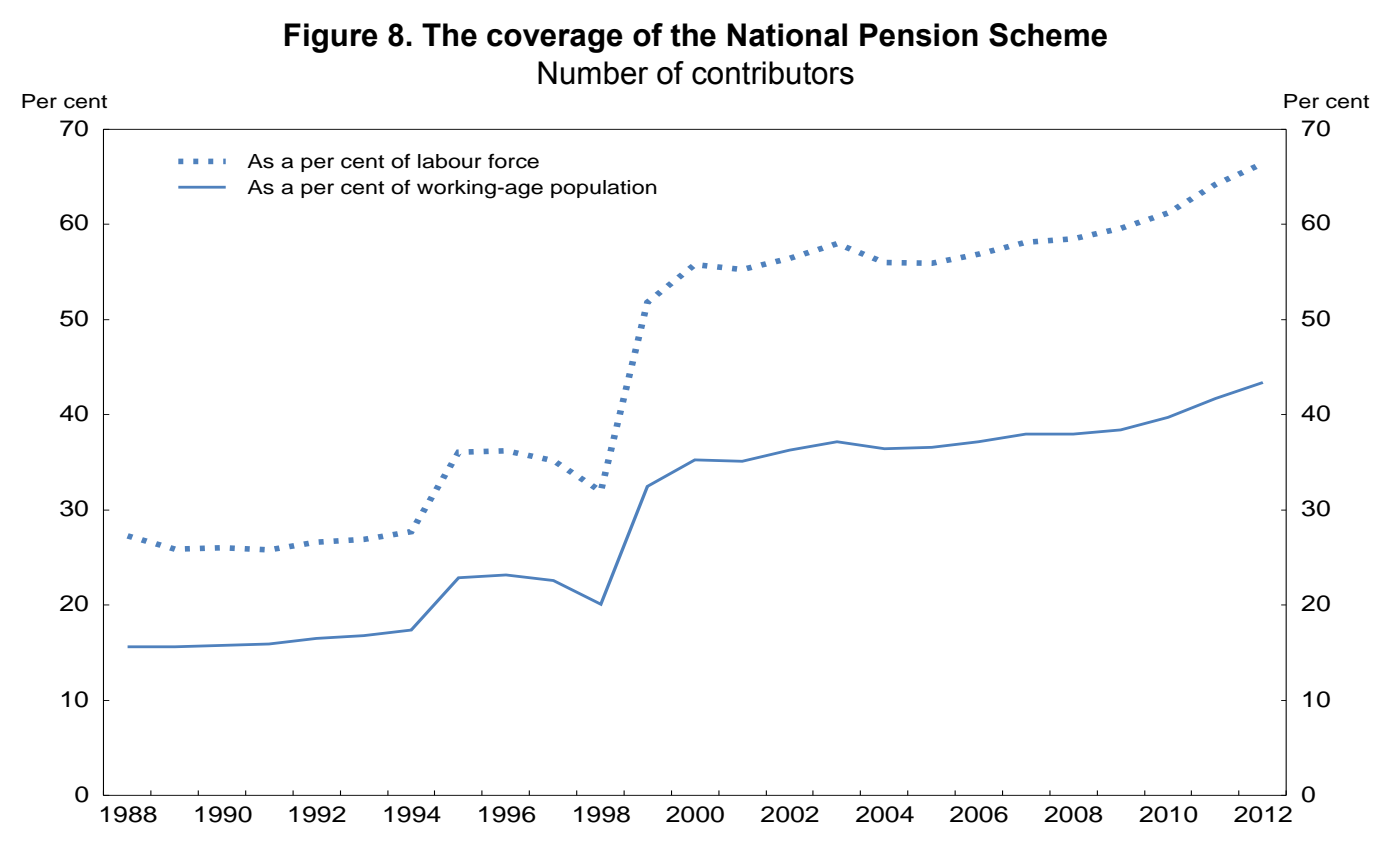

Source: National Pension Service and the Korea National Statistical Office.

16. As for benefits, only $29 \%$ of the elderly in 2013 received old-age pensions from the NPS, which require at least ten years of contributions. Moreover, pension benefits are small at 310 thousand KRW per month (\$298), 10\% of the average wage (Table 1). In sum, the impact of the NPS in reducing elderly poverty is limited by its relatively recent introduction and slow acceptance by the public. Looking ahead, pension benefits will remain low as the targeted replacement rate for a person with 40 years of contributions was reduced from an initial $70 \%$ to $50 \%$ in 2007, and is set to decline to $40 \%$ by 2028 (see below).

3. Although the National Pension Act was enacted in 1973, its implementation was delayed by a number of adverse economic developments, including the two oil shocks.

4. The coverage of the NPS was extended to firms with more than five workers (1992), individuals in rural areas (1995), individuals in urban areas (1999), and firms with one or more workers (2003). 
17. Once it matures, the NPS will have a strong redistributive impact. The gross replacement rate for a worker with earnings of one-half of the median income will be $59 \%$, as against $29 \%$ for a worker earning 1.5 times the median. The 30 percentage-point gap is well above the 22-point average in the OECD area (OECD, 2013a).

\section{Occupational pension schemes}

18. The three occupational pension schemes currently insure 1.5 million workers $(4 \%$ of the working-age population), with the scheme for civil servants accounting for $70 \%$ of the total (Table 2). The occupational pensions have similar benefit structures, which are relatively generous, compared to the NPS. The $76 \%$ replacement rate includes the retirement allowance that private-sector employees receive (see below). The large pension benefit for civil servants is intended to compensate them for relatively low wages and to attract a competent work force with a long-term commitment to public service. The civil service scheme fell into financial troubles in the 1990s, owing to: $i$ ) the generosity of benefits relative to contributions; ii) the rapid ageing of public-sector workers; iii) increasing life expectancy; and iv) the large-scale layoffs of civil servants during the 1997 crisis (Kim and Moon, 2011). Consequently, occupational pensions rely increasingly on government subsidies. In 2009, government spending for the civil servant scheme amounted to $0.6 \%$ of GDP and, despite reforms enacted that year, it is expected to reach $1.1 \%$ in 2030 .

Table 2. Korea's public pension systems ${ }^{1}$

\begin{tabular}{|c|c|c|c|c|c|}
\hline & Introduction & $\begin{array}{l}\text { Contribution } \\
\text { rate }\end{array}$ & $\begin{array}{c}\text { Replacement } \\
\text { rate }^{1}\end{array}$ & $\begin{array}{c}\text { Number of } \\
\text { participants }^{2}\end{array}$ & $\begin{array}{l}\text { Number of } \\
\text { recipients }^{2}\end{array}$ \\
\hline National Pension Scheme & 1988 & $9 \%$ & $40 \%$ & 20.3 & 1.8 \\
\hline Occupational pensions & & & & 1.5 & 0.4 \\
\hline Civil servants & 1960 & $17 \%$ & $76 \%$ & 1.1 & 0.3 \\
\hline Military personnel & 1963 & $17 \%$ & $76 \%$ & 0.2 & 0.1 \\
\hline Private-school teachers & 1975 & $12.6 \%$ & $76 \%$ & 0.3 & 0.0 \\
\hline
\end{tabular}

1. For the National Pension Scheme, this is the rate in 2028 . For the occupational pension schemes, $76 \%$ is the current replacement rate and it is expected to remain at that level.

2. In million people. In 2012 for the National Pension Scheme and 2009 for the occupational pension systems.

Source: Kim (2013) and Kim and Moon (2011).

\section{The second pillar: the company pension system}

19. The weakness of the NPS and the decline in family support left a void that is to be filled in part by company pensions. In 2005, the government launched a plan to encourage the conversion of the mandatory retirement allowance into a company pension to provide better income security for retired workers. The retirement allowance, which was introduced in 1953 and became legally mandatory in 1961, requires firms to pay departing employees a lump-sum equivalent to at least one month of wages per year of work. It was initially intended to be a support for the unemployed and the retired in the absence of unemployment insurance and pensions. Nevertheless, it has a number of weaknesses as a source of retirement income. In particular, the allowance is not secure as it is partially unfunded, although firms receive tax benefits for internally funding it. Moreover, given high labour turnover, with average job tenure of only six years, most workers receive the retirement allowance numerous times during their working life. About $70 \%$ of workplaces with a retirement allowance have paid the allowance prior to retirement at least once, which encourages its use for purposes other than retirement income.

20. The retirement allowance also has negative side effects on the labour market. First, it encourages the hiring of non-regular workers, as most do not receive the allowance (OECD, 2013b). All workers with at least one year of tenure are eligible for the retirement allowance. However, only $45 \%$ of non-regular 
workers with more than one year of tenure received the allowance in 2012. Second, it discourages firms from keeping older workers, given that the retirement allowance is linked to the final salary, which increases with age in Korea's seniority-based wage system. Nevertheless, the retirement allowance remains popular with workers. One study reported that more than $60 \%$ of workers covered by the company pension system were reluctant to shift to the new system (Kim, 2011). One reason has been the favourable tax treatment of retirement allowances over a number of years at low rates. Pressure from workers to maintain the retirement allowance has made it difficult for firms to introduce company pensions.

21. The company pension system allows firms to transform the retirement allowance into a defined benefit (DB) or a defined contribution scheme (DC), in which the contribution is predetermined and the benefit depends on the investment returns. The decision is based on an agreement between management and employees. Companies that introduce a pension are exempt from paying the retirement allowance, although many still do. To promote the shift to company pensions, the government is phasing out the tax deduction for internally-funded retirement allowance plans by 2016 . Nevertheless, only $13.4 \%$ of firms in 2012 had introduced a company pension, with the percentage increasing with firm size, from $9.6 \%$ for firms with less than 10 employees to $86.5 \%$ for firms with more than 500 (Table 3). ${ }^{5}$ The adoption of the company pension system has been slow despite significant tax benefits. All of a firm's contributions to a company pension are deductible. The business sector's resistance to the company pension system reflects in part the requirement that firms must entrust at least $60 \%$ of the funds to financial institutions in the case of DB schemes and $100 \%$ in the case of DC schemes, in contrast to the retirement allowance, which did not have to be funded outside the company. Moreover, firms' contributions under both DB and DC schemes can be as large as those under the retirement allowance.

Table 3. Firms that have established a company pension system

Percentage of firms with company pensions by the number of employees

\begin{tabular}{|c|c|c|c|c|c|c|c|}
\hline & $\begin{array}{c}\text { Total number of } \\
\text { firms with pensions } \\
\text { Thousand firms }\end{array}$ & $\begin{array}{l}\text { Less than } \\
\qquad 10 \\
\text { Per cent }\end{array}$ & $\begin{array}{l}10 \text { to } 100 \\
\text { Per cent }\end{array}$ & $\begin{array}{l}100 \text { to } 299 \\
\text { Per cent }\end{array}$ & $\begin{array}{l}300 \text { to } 499 \\
\text { Per cent }\end{array}$ & $\begin{array}{l}\text { More than } \\
500 \\
\text { Per cent }\end{array}$ & $\begin{array}{l}\text { All firms } \\
\text { Per cent }\end{array}$ \\
\hline 2006 & 16.3 & 0.9 & 2.5 & 3.8 & 2.7 & 6.0 & 1.2 \\
\hline 2007 & 30.9 & 1.6 & 5.4 & 8.4 & 11.6 & 16.0 & 2.2 \\
\hline 2008 & 50.5 & 2.4 & 10.0 & 19.0 & 23.5 & 26.5 & 3.6 \\
\hline 2009 & 70.5 & 2.9 & 14.7 & 28.2 & 31.5 & 39.0 & 4.8 \\
\hline 2010 & 94.5 & 4.0 & 19.1 & 34.9 & 40.2 & 58.6 & 6.4 \\
\hline 2011 & 139.2 & 6.2 & 24.9 & 43.3 & 54.1 & 84.6 & 9.2 \\
\hline 2012 & 203.5 & 9.6 & 31.9 & 48.9 & 61.3 & 86.5 & 13.4 \\
\hline
\end{tabular}

Source: Ministry of Employment and Labour.

22. The share of employees enrolled in company pension schemes reached $24.7 \%$ in 2012 . Among workers eligible for company pension plans - those with more than one year of tenure -- $46 \%$ were enrolled at the end of 2012. Regular workers account for the vast majority of those enrolled in company pensions. Two-thirds are enrolled in DB schemes (Table 4), which are favoured by workers, as they avoid the burden of investing and managing the pension reserves. Moreover, if the combined amount of reserve assets and returns fail to meet the set amount of retirement benefits, the company is legally liable to cover the shortfall. On the other hand, if a DC plan realises a loss, the workers bear the loss in their retirement benefits.

5. The Korea Workers Compensation and Welfare Service, a public institution, provides retirement pension services to workplaces with fewer than 30 employees to reduce the cost of introducing company pensions. 
ECO/WKP(2014)59

Table 4. The number of employees in company pension systems by type of plan

\begin{tabular}{|c|c|c|c|c|c|c|}
\hline & \multirow{2}{*}{$\begin{array}{l}\text { Employees enrolled in } \\
\text { company pensions }\end{array}$} & \multirow{2}{*}{$\begin{array}{l}\text { Share of total } \\
\text { employees }\end{array}$} & \multirow{2}{*}{$\begin{array}{l}\text { Share of employees } \\
\text { employed at least one year }{ }^{1}\end{array}$} & \multicolumn{3}{|c|}{ Enrolled employees by type of plan } \\
\hline & & & & DB plan & DC plan & $\mathrm{IRP}^{2}$ \\
\hline & Thousand employees & Per cent & Per cent & Per cent & Per cent & Per cent \\
\hline 2006 & 213 & 1.4 & 3.1 & 39.2 & 43.6 & 17.2 \\
\hline 2007 & 535 & 3.4 & 7.5 & 51.4 & 38.5 & 10.1 \\
\hline 2008 & 1115 & 6.9 & 15.2 & 63.3 & 31.1 & 5.6 \\
\hline 2009 & 2470 & 15.0 & 32.3 & 76.9 & 20.3 & 2.8 \\
\hline 2010 & 2394 & 14.1 & 27.0 & 68.8 & 28.2 & 3.0 \\
\hline 2011 & 3284 & 17.3 & 36.0 & 69.3 & 28.3 & 2.4 \\
\hline 2012 & 4377 & 24.7 & 46.0 & 63.3 & 34.7 & 2.0 \\
\hline
\end{tabular}

1. Workers who have worked one year or longer at a company are eligible for company pensions.

2. Individual Retirement Pension.

Source: Ministry of Employment and Labour.

23. Given its recent introduction, only 130 thousand (3\%) of those enrolled in company pensions received payments, which are limited to those aged 55 and over. The replacement rate of company pensions is estimated to be $12.5 \%$ (Chung, 2010). The total reserves of company pension systems reached $5.3 \%$ of GDP in 2012, with DB schemes accounting for $73.8 \%$ of the total (Table 5). At the end of 2012, $93 \%$ of company pension reserves were invested in financial vehicles with principal protection, such as time deposits. Consequently, $83 \%$ are held in instruments with a maturity of less than one year (Nam, 2013). Repeatedly rolling over short-term investments is a poor strategy for pensions, given their long-term nature, and leads to low returns. Moreover, the concentration of reserves in short-term, principal-protected instruments hinders the development of Korea's capital markets

\section{Programmes to encourage individual savings}

24. Voluntary individual pension accounts, which are open to individuals regardless of their employment status, were introduced in 1994. There are about 660 personal pension products offered by insurance companies, banks and asset management companies. Individuals who contribute a specified amount of money for more than five years are entitled to receive monthly pensions starting at age 55 . They are allowed a tax credit of up to $12 \%$ of the amount placed in such accounts up to a ceiling of 4 million KRW ( $\$ 3850)$ a year. Taxation, which is deferred until the individual begins receiving benefits at age 55, is set at a rate of $3.3 \%$ to $5.5 \%$, depending on the recipient's age. The replacement rate of the individual pension accounts has been estimated at $7.5 \%$ (Chung, 2010).

Table 5. Company pension reserves by type of pension plan

In trillion KRW

\begin{tabular}{|c|c|c|c|c|c|c|c|c|c|c|}
\hline \multirow{3}{*}{ Year } & \multirow{2}{*}{\multicolumn{2}{|c|}{$\begin{array}{c}\text { Defined } \\
\text { benefits (DB) }\end{array}$}} & \multirow{2}{*}{\multicolumn{2}{|c|}{$\begin{array}{c}\text { Defined } \\
\text { contribution (DC) }\end{array}$}} & \multicolumn{4}{|c|}{ Individual Retirement Pesion (IRP) } & \multirow{2}{*}{\multicolumn{2}{|c|}{ Total }} \\
\hline & & & & & \multicolumn{2}{|c|}{ Business } & \multicolumn{2}{|c|}{ Individual } & & \\
\hline & Value & $\begin{array}{l}\text { Per } \\
\text { cent }\end{array}$ & Value & $\begin{array}{l}\text { Per } \\
\text { cent }\end{array}$ & Value & $\begin{array}{l}\text { Per } \\
\text { cent }\end{array}$ & Value & $\begin{array}{l}\text { Per } \\
\text { cent }\end{array}$ & Value & $\begin{array}{l}\text { Per } \\
\text { cent }\end{array}$ \\
\hline 2006 & 0.1 & 66.3 & 0.0 & 26.5 & 0.0 & 6.7 & 0.0 & 0.4 & 0.1 & 100.0 \\
\hline 2007 & 1.8 & 66.3 & 1.0 & 25.5 & 0.0 & 4.8 & 0.0 & 3.4 & 2.8 & 100.0 \\
\hline 2008 & 4.6 & 69.3 & 2.0 & 24.4 & 0.0 & 4.1 & 0.0 & 2.2 & 6.6 & 100.0 \\
\hline 2009 & 10.1 & 71.7 & 3.0 & 21.3 & 0.0 & 2.7 & 0.1 & 4.4 & 14.0 & 100.0 \\
\hline 2010 & 21.0 & 72.0 & 5.2 & 17.7 & 0.1 & 1.9 & 2.5 & 8.5 & 29.0 & 100.0 \\
\hline 2011 & 38.0 & 75.2 & 8.1 & 16.2 & 0.1 & 1.2 & 3.7 & 7.3 & 49.9 & 100.0 \\
\hline 2012 & 50.0 & 73.8 & 12.0 & 17.8 & 0.1 & 1.0 & 5.0 & 7.5 & 67.3 & 100.0 \\
\hline
\end{tabular}

Source: Ministry of Employment and Labour. 
25. The total amount of assets rose from 43.3 trillion KRW at the end of 2008 (4.5\% of GDP) to 86.4 trillion KRW (6.5\%) in 2013 (Table 6). Meanwhile, the number of contracts increased by 55\% to nearly 6.3 million. However, assuming one contract per person, the number of voluntary individual retirement accounts would cover only $17 \%$ of the working-age population, compared to $30 \%$ in Germany and $25 \%$ in the United States. Moreover, a substantial number of individuals withdraw their funds early before reaching age 55. The share of investors closing their account rises from $28 \%$ after five years to $48 \%$ after ten years. The assets are managed in a conservative manner, divided between government treasuries and corporate bonds $(55.2 \%)$, loans and receivables (19.4\%), cash and deposits $(4.6 \%)$ and equities $(4.2 \%)$, reflecting investors' preference for stable asset management. Indeed, $94 \%$ of the products in the accounts guarantee both principal and interest.

Table 6. Voluntary individual pension accounts ${ }^{1}$

Assets (in trillion KRW) and the number of contracts (in thousands)

\begin{tabular}{l|r|r|r|r|r|c}
\hline & \multicolumn{2}{|c|}{$2008^{2}$} & \multicolumn{2}{c|}{$2011^{2}$} & \multicolumn{2}{c}{$2013^{3}$} \\
\cline { 2 - 7 } & Assets & $\begin{array}{c}\text { Number of } \\
\text { contracts }\end{array}$ & Assets & $\begin{array}{c}\text { Number of } \\
\text { contracts }\end{array}$ & Assets & $\begin{array}{c}\text { Number of } \\
\text { contracts }\end{array}$ \\
\hline Banks & 11.0 & 1112 & 11.8 & 991 & 12.5 & 956 \\
Investment trust & 2.0 & - & 3.9 & - & 5.4 & - \\
management companies & 23.3 & 1984 & 33.8 & 2357 & 46.8 & 2888 \\
Life insurance companies & 7.0 & 906 & 13.1 & 1914 & 19.2 & 2199 \\
$\begin{array}{l}\text { Non-life insurance } \\
\text { companies }\end{array}$ & 0.0 & 0 & 5.6 & 502 & 2.6 & 223 \\
Other $^{4}$ & 43.3 & 4002 & 68.2 & 5764 & 86.4 & 6266 \\
\hline Total & & & & & \\
\hline
\end{tabular}

1. Limited to accounts with tax benefits.

2. End of year.

3. End of September.

4. Credit unions, fishery co-operatives, Saemaul Finance Associations, postal savings and insurance, etc.

Source: Financial Supervisory Commission

\section{Longer-term challenges to reducing elderly poverty}

26. Rapid population ageing in Korea will exacerbate elderly poverty during the coming decades in the context of a weak framework for public and private support for older persons. The fertility rate fell from 4.5 in 1970 to 1.2 in 2002 and remains close to that level, the lowest in the OECD area. Meanwhile, life expectancy has risen to the OECD average. Consequently, Korea is projected to experience the most rapid population ageing among OECD countries, transforming its population from the fourth youngest in 2010 to the third oldest in 2050 (Figure 9). The number of persons of working age is projected to fall from 6.0 per elderly in 2010 to only 1.3 in 2050 . Demographic trends will thus increase the burden on the working-age population and may further reduce family support.

27. However, even in the long term, the NPS will be insufficient to prevent poverty among the elderly given its low coverage (Figure 8), the limited contribution history of pension recipients and the low targeted replacement rate. According to the government's 2013 projection, $40.9 \%$ of the elderly in 2030 will receive old-age pensions (Table 7). Even with policies to boost the share of the population covered by the NPS, such as subsidies for the contributions of low-income workers and enhanced enforcement, onethird of the population aged 18 to 59 will not be registered as insured by the NPS in 2030. In addition to the low coverage of the self-employed, participation is also low among non-regular workers: in 2011, only $38 \%$ of non-regular workers were covered in their workplaces compared to $79 \%$ of regular workers. The low participation rate in the NPS will limit the number of elderly who complete the minimum ten years of contributions necessary to receive benefits. 
Figure 9. Population ageing in Korea is projected to be the fastest in the OECD area

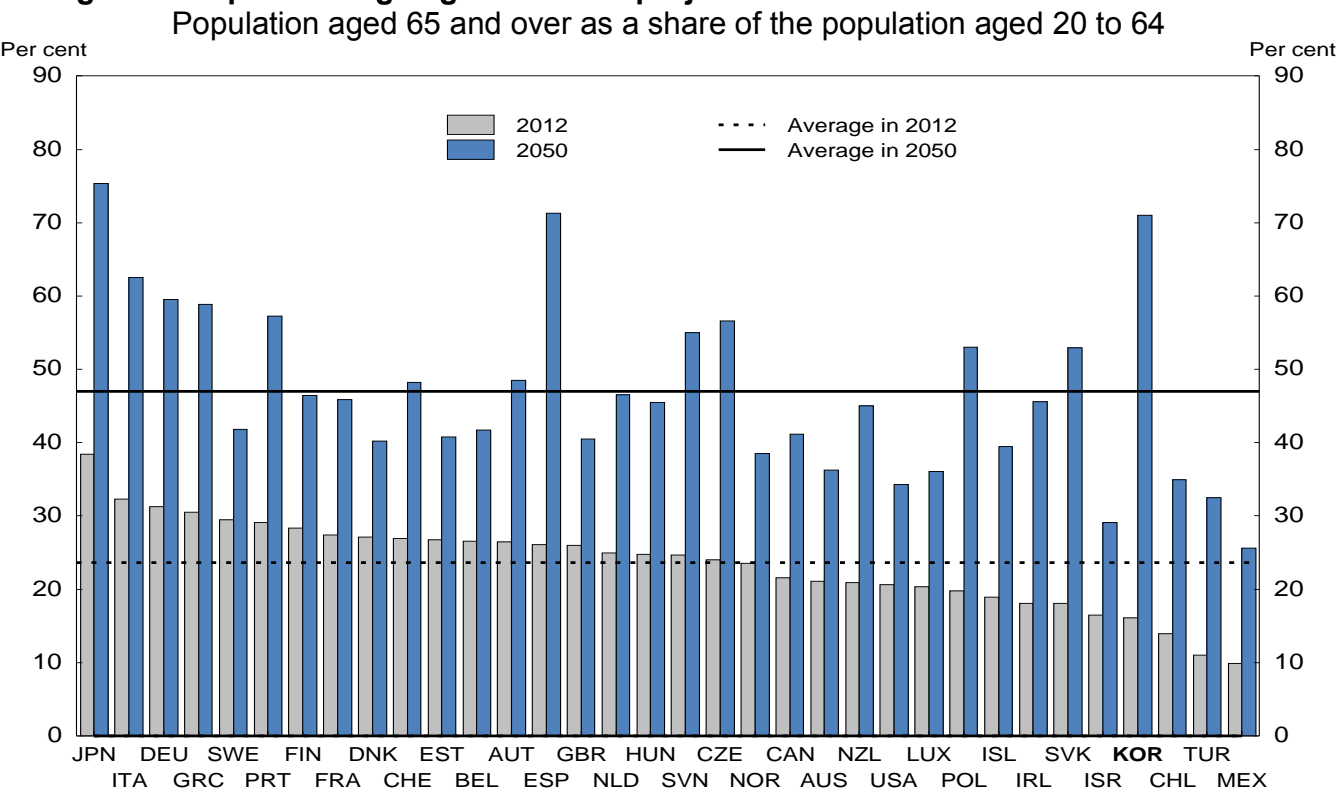

Source: OECD Demography and Population Database.

28. Moreover, the average contribution period of pension recipients over 2030-40 is projected to be less than half of the full period of 40 years on which the $40 \%$ replacement rate is based. In addition to the gaps in coverage, this reflects the practice of retirement even before the mandatory retirement age, which firms set at an average age of 57 in 2010. With a contribution period of less than 20 years, the average replacement rate for the elderly qualifying for an old-age NPS pension would be less than $20 \%$, which is below the minimum cost of living.

Table 7. Long-term projections of the coverage of the National Pension Scheme In thousand people

\begin{tabular}{l|cc|cc|cc|cc}
\hline & \multicolumn{2}{|c|}{ Population } & \multicolumn{2}{c|}{ Insured persons } & \multicolumn{3}{c}{ Pension recipients (over 65) } \\
\cline { 2 - 9 } & $18-59$ & Over 65 & \multicolumn{2}{|c|}{ Old Age } & \multicolumn{2}{c}{ Disability or Survivor } \\
& (A) & (B) & (C) & C/A & (D) & D/B & (E) & E/B \\
\hline 2013 & 32316 & 6138 & 20396 & 63.1 & 1782 & 29.0 & 233 & 3.8 \\
2015 & 32367 & 6624 & 20621 & 63.7 & 2056 & 31.0 & 308 & 4.6 \\
2020 & 31395 & 8084 & 20367 & 64.9 & 2764 & 34.2 & 547 & 6.8 \\
2025 & 29377 & 10331 & 19579 & 66.6 & 3803 & 36.8 & 847 & 8.2 \\
2030 & 27415 & 12691 & 18627 & 67.9 & 5194 & 40.9 & 1173 & 9.2 \\
2040 & 23792 & 16501 & 16823 & 70.7 & 8972 & 54.4 & 1774 & 10.8 \\
2050 & 21045 & 17991 & 15479 & 73.6 & 12310 & 68.4 & 2187 & 12.2 \\
2060 & 17730 & 17622 & 13573 & 76.6 & 13857 & 78.6 & 2230 & 12.7 \\
\hline
\end{tabular}

Source: National Pension Research Institute (2013), 2013 Actuarial Projection (Result of the 3rd Financial Review).

29. In addition to the low level, the variation in pension benefits is likely to be high for several reasons. First, Korea has a high degree of wage inequality. A quarter of full-time workers in Korea earn less than two-thirds of the median wage, the highest share in the OECD area, reflecting low wages for nonregular workers (2014 OECD Economic Survey of Korea). Moreover, overall earnings dispersion for fulltime workers, measured by the ratio of the $9^{\text {th }}$ decile to the $1^{\text {st }}$, was the third highest. Second, the length of 
contribution periods is likely to vary significantly. The overall average of less than 20 years implies that longer contribution histories for regular workers, at 30 years or more, would be offset by much shorter periods for self-employed and non-regular workers. Consequently, there is a risk that the pension benefits of non-regular workers and the self-employed will fall well below the minimum cost of living.

30. Finally, there is a large gender gap in terms of the level of coverage and the amount of benefits. While $28 \%$ of persons aged 65 and over received NPS old-age pension benefits in 2011, the proportion is much higher for men (40\%) than for women (15\%). Moreover, the average benefit for women was only $60 \%$ of that for men, reflecting their shorter contribution histories and concentration in non-regular employment where wages are relatively low (Kim, 2011). Higher non-regular employment, as well as the lower female labour force participation rate, also results in a smaller share of women (at 36\%) paying pension contributions than men (50\%). The government acknowledges that "policies to adequately provide women's pension rights are not still sufficient in Korea" (Government of Korea, 2013).

31. In addition to its limited impact on elderly poverty, the NPS is not financially sustainable according to the government's 2013 projection. Under the current parameters (a 9\% contribution rate, a $40 \%$ replacement rate for an average earner with 40 years of contributions and a hike in the pension eligibility age from 61 to 65 by 2033), expenditures would surpass revenue, including contributions and investment earnings, in 2044 (Table 8). By that point, pension expenditures are projected to reach $4.8 \%$ of GDP, reflecting rapid population ageing. The National Pension Fund, already the third largest in the world, is expected to climb to 50\% of GDP by 2035 (National Pension Research Institute, 2013). However, the deficits beginning in 2044 would exhaust the Fund by 2060, while the annual deficit would reach $4.1 \%$ of GDP (Figure 10). The 2013 government projection estimated that maintaining a balanced budget through 2083 would require boosting the contribution rate to $14.1 \%$ by 2015 . A reform of the NPS is thus required to ensure its sustainability, while at the same time addressing the issue of inadequate pension coverage and high poverty among the elderly.

Table 8. Long-term projections of the financial balance of the National Pension Scheme

\begin{tabular}{|c|c|c|c|c|c|c|c|c|}
\hline & \multicolumn{2}{|c|}{ National Pension Fund } & \multicolumn{2}{|c|}{ Income } & \multicolumn{2}{|c|}{ Expenditure } & \multicolumn{2}{|c|}{ Balance } \\
\hline & $\begin{array}{l}\text { Trillion } \\
\text { KRW }\end{array}$ & $\begin{array}{c}\text { Per cent of } \\
\text { GDP }\end{array}$ & $\begin{array}{l}\text { Trillion } \\
\text { KRW }\end{array}$ & $\begin{array}{l}\text { Per cent of } \\
\text { GDP }\end{array}$ & $\begin{array}{l}\text { Trillion } \\
\text { KRW }\end{array}$ & $\begin{array}{l}\text { Per cent } \\
\text { of GDP }\end{array}$ & $\begin{array}{l}\text { Trillion } \\
\text { KRW }\end{array}$ & $\begin{array}{l}\text { Per cent } \\
\text { of GDP }\end{array}$ \\
\hline 2013 & 417.7 & 31.1 & 52.2 & 3.9 & 14.6 & 1.1 & 37.7 & 2.8 \\
\hline 2020 & 847.2 & 39.3 & 109.1 & 5.1 & 33.9 & 1.6 & 75.2 & 3.5 \\
\hline 2030 & 1732.4 & 47.8 & 186.9 & 5.2 & 90.0 & 2.5 & 97.0 & 2.7 \\
\hline 2040 & 2494.5 & 47.4 & 258.4 & 4.9 & 213.8 & 4.1 & 44.7 & 0.9 \\
\hline 2043 & 2561.5 & 44.2 & 277.6 & 4.8 & 267.3 & 4.6 & 10.3 & 0.2 \\
\hline 2044 & 2558.7 & 42.7 & 283.7 & 4.7 & 286.5 & 4.8 & -2.8 & 0.0 \\
\hline 2045 & 2541.4 & 41.1 & 289.4 & 4.7 & 306.8 & 5.0 & -17.4 & -0.3 \\
\hline 2050 & 2200.5 & 30.5 & 309.8 & 4.3 & 414.1 & 5.7 & -104.3 & -1.4 \\
\hline 2060 & -280.7 & -2.9 & 263.4 & 2.8 & 657.8 & 6.9 & -394.4 & -4.1 \\
\hline
\end{tabular}

Source: National Pension Research Institute (2013), 2013 Actuarial Projection (Result of the 3rd Financial Review). 
Figure 10. Long-run projections for the National Pension Scheme

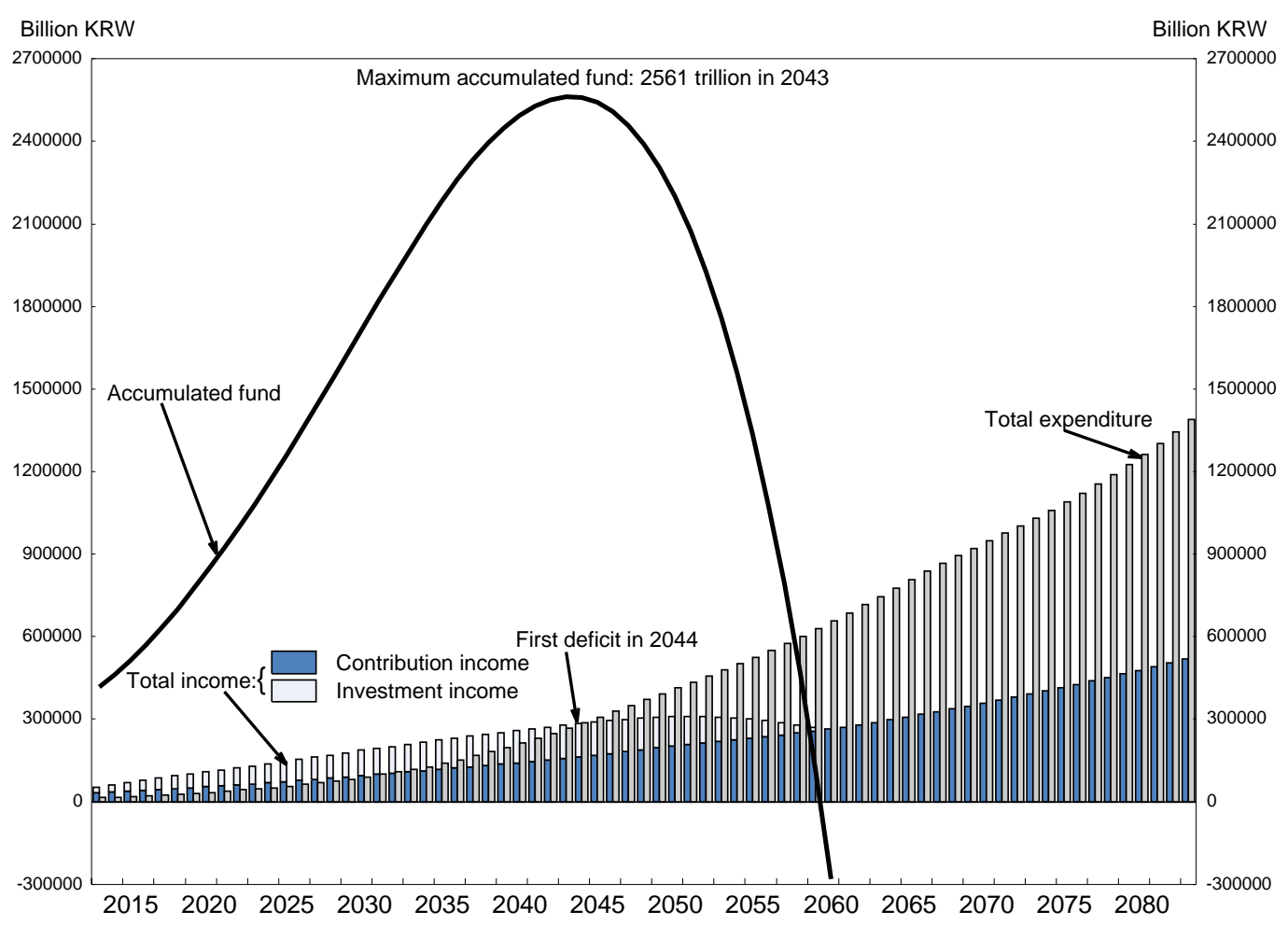

Source: National Pension Research Institute (2013).

\section{A comprehensive approach to addressing elderly poverty}

32. An effective multi-pillar approach based on a social consensus is necessary to ensure adequate retirement income and reduce poverty among the elderly. This should include well-targeted social spending (the zero pillar, as shown in Figure 5), reforms to the public pension system (the first pillar) and measures to increase private savings by developing the company pension system (the second pillar) and individual pension savings (the third pillar). All the pillars have been established in Korea during the past 25 years but are still at an early stage of development (Chung, 2010). Moreover, it is essential that the pillars, which have competed vigorously to expand their coverage, function smoothly together (Kim, 2013a).

\section{Immediate priorities to reduce elderly poverty}

33. Given the inadequacy of the NPS, the immediate priority is well-targeted social spending to ensure an adequate minimum level of income for the elderly. As noted above, the government plans to double the BOAP to 200 thousand KRW (\$193) per month, while keeping the coverage virtually unchanged. The new benefit would be about $6 \%$ of the average wage, still well below the $31 \%$ average in OECD countries with non-contributory benefits that are means-tested (Figure 7). Although there is no estimate of the impact of the expansion of the BOAP on Korea's $49 \%$ relative poverty rate, it is likely to be limited, leaving it far above the $13 \%$ OECD average.

34. Moreover, it is uncertain what impact it would have on the share of elderly in absolute poverty, but the rate is also likely to remain high. Clearly, the BLSP has not achieved its goal of ensuring that all poor, including the elderly, have an income that at least matches the minimum cost of living. This reflects the eligibility conditions that limit the share of elderly receiving the BLSP to $6 \%$. Eliminating the "family support obligation rule" would sharply increase the share of elderly recipients, but the government believes 
that getting rid of this rule would create a moral hazard that would discourage families from assisting their elderly relatives.

35. Inasmuch as the BLSP has not achieved the goal of ensuring that all poor have an income that at least matches the minimum cost of living, the BOAP could play that role for the elderly. To stay within budget constraints, this would require narrowing the coverage of the BOAP to provide larger benefits to the elderly below the minimum cost of living, in line with the BOAP's stated goal of aiding the "financially distressed" (Yun, 2013). As poverty and income inequality are much higher among the elderly than the working age population, narrowing the BOAP's coverage and increasing its benefits is appropriate. The target should be to lift all elderly with an income below the minimum cost of living up to that threshold, which is currently set at 603 thousand KRW per month (Table 1). This would likely be less expensive than the government's new proposal, which would cost close to 40 trillion KRW (3.1\% of 2012 GDP). ${ }^{6}$

36. With the 2014 reform increasing the threshold for in-kind BLSP benefits from $40 \%$ of median income to $40 \%-50 \%$, the BLSP could top up the income of poor elderly. At the same time, the proportion of elderly receiving the BLSP should be increased from the current $6 \%$ by further relaxing the treatment of home ownership by the BLSP and the "family support obligation rule". Finally, the government needs to step up its efforts to ensure that all the elderly who are eligible for the BLSP actually receive it (OECD, 2013b).

37. Measures to enhance the employability of older workers would help increase the share that work beyond the pension eligibility age, currently set at 61 , thus increasing labour income and reducing poverty. The NPS encourages work, as the increase in pension wealth for men who work from 60 to 65 in Korea is the sixth highest in the OECD area (OECD, 2013a). Moreover, in 2012, 43\% of the 65-to-69 age cohort was working, almost double the OECD average of $23 \%$. However, $59 \%$ of men working past the age of 65 are self-employed (Lee and Lee, 2011). Increasing employment opportunities for older persons depends in part on vocational training, given the relatively low educational attainment of this age cohort.

38. The biggest obstacle to employment of older persons is the relatively young age at which workers leave firms. The average mandatory retirement age set by firms is 57 and many workers depart even earlier, as the importance of seniority in determining salaries makes firms anxious to reduce the number of high-wage older workers. The decision to raise the minimum age for mandatory retirement to 60 in big firms (i.e., with more than 300 workers) beginning in 2016 is a step in the right direction. The minimum should gradually be raised further to 65 . In the long run, the goal should be to eliminate the right of firms to set a mandatory retirement age (2012 OECD Economic Survey of Korea). Eliminating mandatory retirement would have a double dividend of increasing the number of contributors to the NPS and limiting the number of pensioners to be supported. The abolition of mandatory retirement is often opposed on the grounds that it could reduce employment opportunities for young people. However, this argument is based on the fallacy that an economy has a fixed number of jobs. In reality, limiting employment opportunities for some workers - such as older people - simply decreases economic activity (OECD, 2006). Indeed, the employment rates for younger and older workers across OECD countries are positively correlated and the correlation is statistically significant (Figure 11).

6. Assuming that the average income of the elderly with an income below the minimum cost of living was one-half of that threshold, the cost of bringing their income up to the minimum cost of living would cost around 38 trillion KRW between 2014 and 2017. 
Figure 11. Employment rates of younlger and older workers

Percentage of 55-59 year-olds and 20-24 year-olds in employment in $2010^{1}$

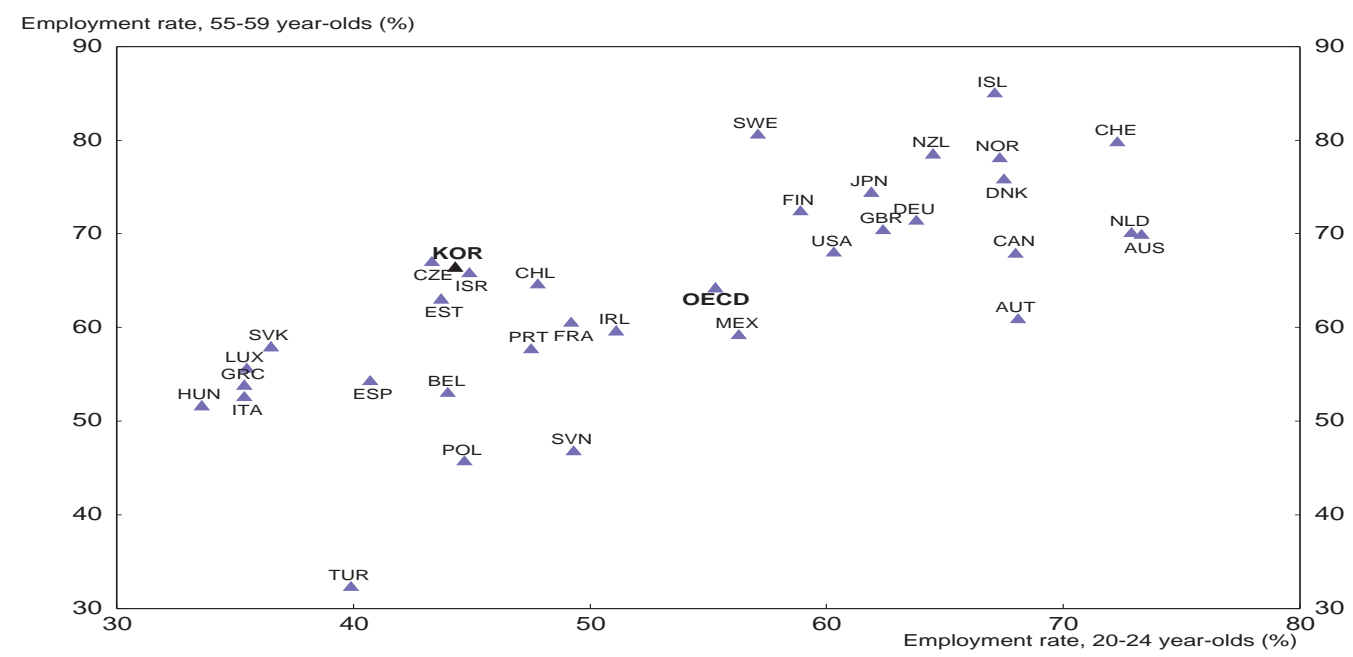

1. The correlation coefficient is 0.53 .

Source: OECD ELS Database.

\section{Reforming the NPS to ensure its sustainability}

Three options to achieve financial sustainability

39. The NPS faces a difficult challenge of expanding coverage to alleviate poverty among the elderly while ensuring its long-term solvency (Kim, 2013b). The reforms implemented in 1998 and 2007 failed to meet this challenge. There are three main options to achieve sustainability - cutting pension benefits, raising the pension eligibility age and hiking the contribution rate. In the previous reform efforts, there was a clear public preference for cutting benefits, rather than raising contributions. Such a preference is not surprising given that cuts in benefits are only felt well in the future while the pain of higher contributions is immediate. Consequently, the reforms reduced the replacement rate from $70 \%$ to $40 \%$ by 2028 , as noted above. Given its current low level, further cuts in the replacement rate are not realistic and, instead, the planned cut to $40 \%$ should be reconsidered (see below).

40. As for the second option, the projected life expectancy at the pension eligibility age in Korea rose from 16.2 years for men and 20.8 for women in 1993 to 20.2 and 25.2, respectively, in 2010, the secondlargest increase among OECD countries. Moreover, the figure for Korea was about two years longer than the OECD average (Figure 12). The projected life expectancy at the pension eligibility age in 2030 is projected to remain close to its 2010 level, as rising life expectancy offsets the gradual hike in the pension eligibility age to 65 in 2033. One option would be accelerate the hike in the pension eligibility age. However, this would create hardship for workers by lengthening the gap between the time when they leave firms and when they become eligible for a public pension. 
Figure 12. Life expectancy at the pensionable age in years

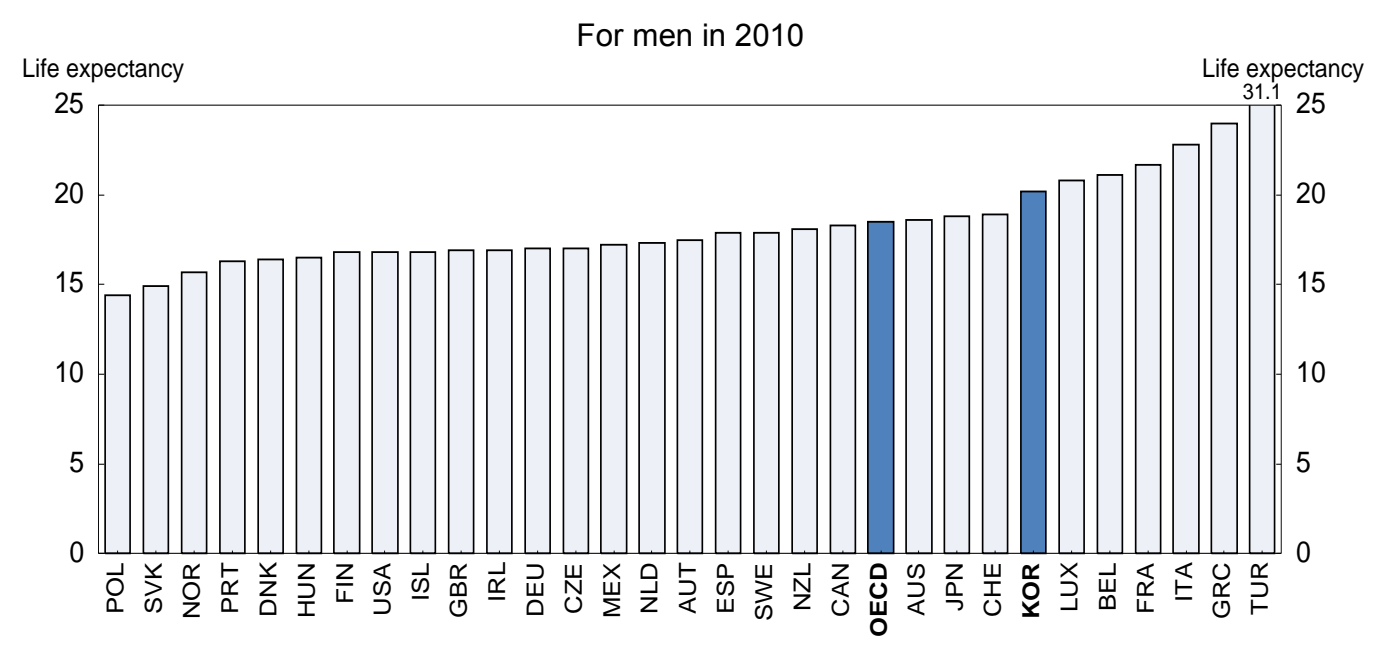

Source: OECD (2011a).

41. Given that a cut in the replacement rate of pension benefits and a hike in the pension eligibility age are not feasible at present, the remaining option is to raise more revenue. However, there is opposition to hikes in the contribution rate, as some argue that the partially-funded NPS should be transformed into a pay-as-you-go system. It would thus become a social welfare system that transfers wealth between generations. Such an approach would allow the contribution rate to be reduced to $3.7 \%$ at present, reflecting the NPS's immaturity. However, the rate would have to rise rapidly in the future, reaching $21.4 \%$ by 2060 . Moreover, pay-as-you-go systems have trouble coping with population ageing, a serious concern in Korea, given its exceptionally rapid demographic change (Figure 9). In addition, it would reduce inter-generational equity, while the high contribution rates needed in the future would raise the gap between labour costs (wages plus social insurance paid by firms) and the take-home pay of workers, thereby reducing employment. Moreover, there is evidence that unfunded social security pensions reduce aggregate saving and hence capital accumulation and growth (Feldstein, 1996).

42. It is therefore important to raise more revenue. Although some countries rely on general tax revenue to finance pensions, this would not be appropriate in Korea, where only $41 \%$ of the elderly will receive an NPS pension in 2030. Relying on general tax revenue to fund the NPS would, in effect, transfer income from low-income persons, such as non-regular workers and those in SMEs, who are less likely to participate in the NPS, to higher-income persons. Instead, the priority is to raise the contribution rate, which has been set at 9\% since 1998, the second lowest in the OECD area and well below the OECD average of $19.6 \%$ (Figure 13). The low pension contribution rate has helped limit Korea's marginal tax wedge on labour, which is the third lowest in the OECD area. Nevertheless, raising the contribution rate is the best way to finance the NPS.

43. The 2013 government projection estimated that balancing the NPS budget through 2083 would require boosting the contribution rate to $14.1 \%$ by 2015 . However, legislation to boost the rate to $15.9 \%$ by 2030 was rejected in 2003 . If the contribution rate were left permanently at $9 \%$, the replacement rate would eventually have to fall by half to around $20 \%$ to maintain the financial balance of the NPS, assuming that the government continues to rely on contributions to finance the NPS.

44. The required increase in the contribution rate depends on the financial objective. The NPS has not set an objective for financial sustainability, but instead proposed four possible targets in their 2013 projection (Table 9). The easiest - maintaining the National Pension Fund at two times annual pension outlays -- would require a $12.91 \%$ contribution rate from 2015 . The most ambitious - maintaining a stable Fund-to-expenditure ratio from the $2050 \mathrm{~s}$-- would require a much higher contribution rate of $15.85 \%$. 
Figure 13. International comparison of pension contribution rates

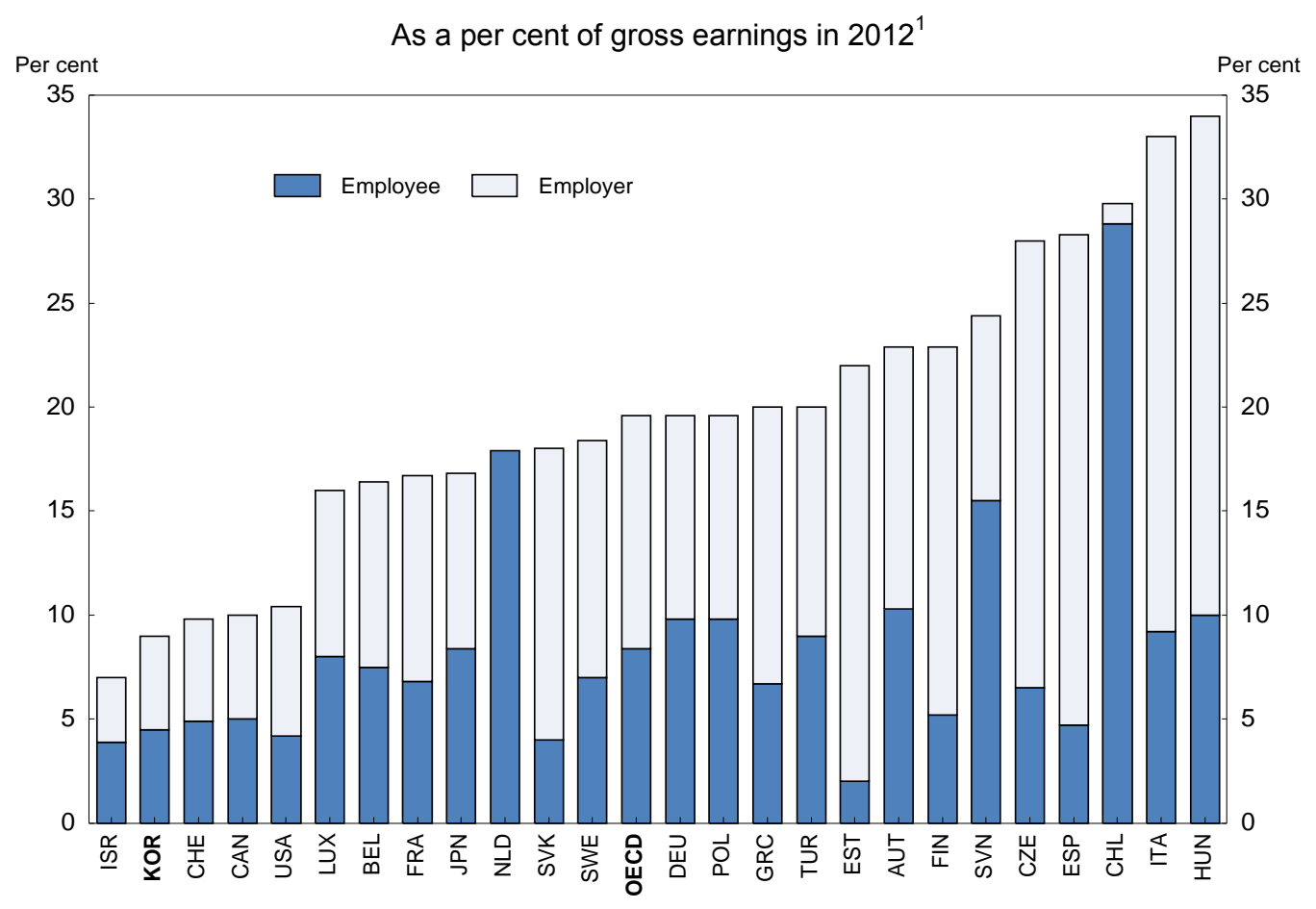

1. For 25 countries as some OECD countries have no separate pension contributions or private pensions only.

Source: OECD (2013a).

45. The new government has ruled out an increase in the contribution rate during its term, which ends in 2018. However, given the speed of population ageing, the increase in the contribution rate should begin as soon as possible, rather than waiting for the next president to take office, in order to limit the size of the hike in the contribution rate that will be necessary. According to a 2012 study by a government research institute, the long-run equilibrium contribution rate is higher if the starting date is delayed (Table 10). For example, if the contribution rate increased for two decades beginning in 2013 to ensure that the Fund would be at least two times annual pension outlays in 2080 , the rate would have to rise to $13.7 \%$. However, if the hike in the contribution rate were delayed to 2023 , the rate would have to rise to $14.95 \%$.

46. Improving the sustainability of the NPS by hiking the contribution rate would boost confidence in the Scheme, thereby encouraging participation. In addition, it would improve inter-generational equity (Kim, 2013b). However, as the number of insured persons and pension recipients increases, it will become increasingly difficult to implement reforms. NPS reform needs to strike a balance between avoiding abrupt parametric reforms that could further reduce confidence, while limiting the need for frequent reform attempts, which have created uncertainty and conflict. In addition to the changes implemented in 1998 and 2007, the 2003 reform proposed by the government was rejected by the National Assembly.

Table 9. Contribution rates required to accomplish financial goals

\begin{tabular}{lccc}
\hline & & \multicolumn{2}{c}{ Financial goal } \\
\cline { 2 - 3 } & $\begin{array}{l}\text { Fund-to-expenditure } \\
\text { ratio of two in 2083 }\end{array}$ & $\begin{array}{l}\text { Fund-to-expenditure } \\
\text { ratio of five in 2083 }\end{array}$ & $\begin{array}{l}\text { No loss in the Fund's } \\
\text { balance through 2083 }\end{array}$ \\
\hline $\begin{array}{l}\text { Required } \\
\text { contribution rate }\end{array}$ & $12.91 \%$ & $13.48 \%$ & $14.11 \%$ \\
\hline
\end{tabular}

Source: National Pension Research Institute (2013). 
Table 10. The impact of delaying hikes in the pension contribution rate Contribution rate

\begin{tabular}{lcc|c}
\hline \multicolumn{2}{c|}{2080 target } & \multicolumn{2}{c}{2100 target } \\
\hline Starting date & Two times $^{1}$ & Five times $^{1}$ & Two times $^{1}$ \\
\hline $2013^{2}$ & $13.70 \%$ & $14.65 \%$ & $16.30 \%$ \\
$2023^{3}$ & $14.95 \%$ & $16.20 \%$ & $17.80 \%$ \\
\hline
\end{tabular}

1. The ratio of the National Pension Fund to annual pension expenditures in 2080 or 2100.

2. Assumes a gradual hike in the contribution rate over the period $2013-33$ from the current $9 \%$ to the level shown in the table.

3. Assumes a gradual hike in the contribution rate over the period 2023-33 from the current $9 \%$ to the level shown in the table.

Source: Yun et al. (2012).

\section{Increasing the return on the National Pension Fund}

47. Pension reform should also aim at boosting the return on the National Pension Fund so as to limit the necessary rise in the contribution rate. The Fund has been reducing its traditional reliance on domestic bonds in favour of equities, while increasing the share of overseas assets, to enhance returns on a riskadjusted basis and achieve the long-term financial stability of the NPS (NPS, 2012b). Indeed, the share of fixed-income assets fell from $87.2 \%$ in 2006 to $68.0 \%$ in the first half of 2012 , while the share of equities doubled to $23.9 \%$ (Figure 14). The shift is positive for investment income, as the return on the Fund's holdings of domestic equities has been $9 \%$ a year since the NPS's inception in 1988, compared to $6 \%$ for domestic fixed-income assets (NPS, 2012b).

Figure 14. The diversification of the National Pension Fund
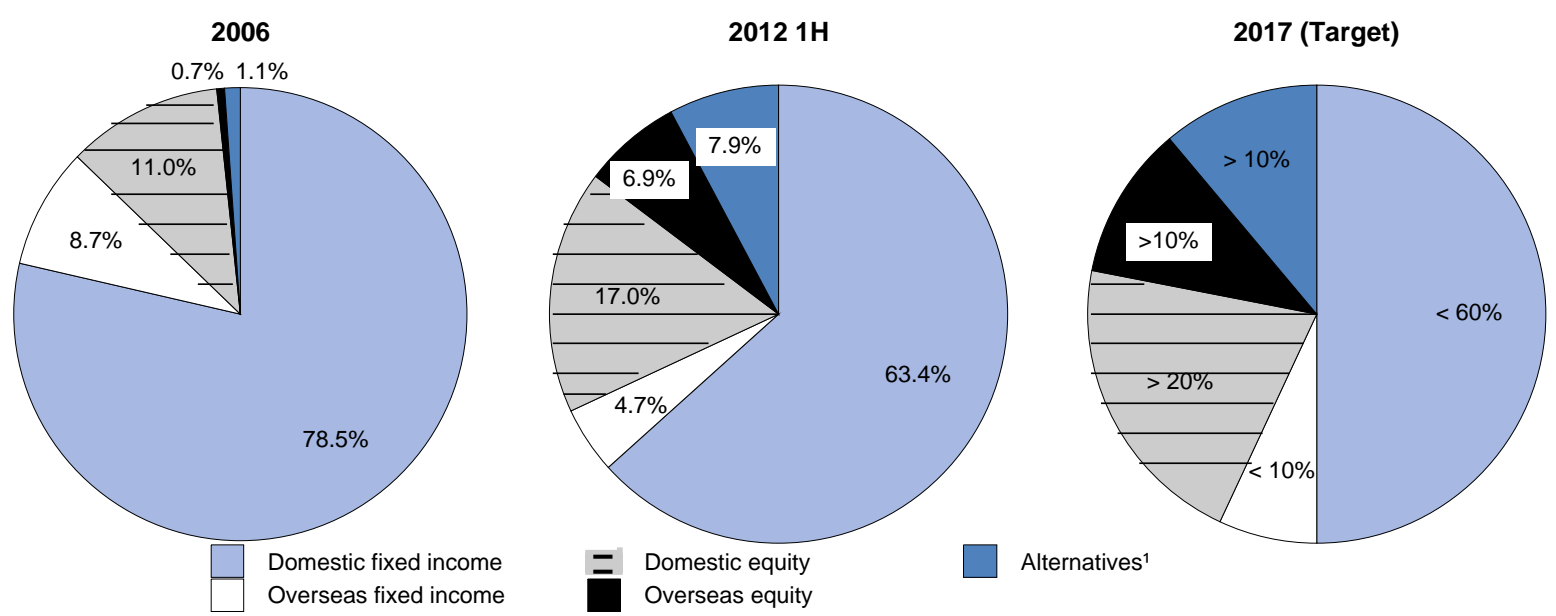

1. Alternative assets are split almost equally between domestic and foreign investments. In terms of assets, it is divided into three almost equal shares; i) social overhead capital (primarily domestic); ii) real estate (primarily overseas); and iii) other, such as venture businesses.

Source: National Pension Service (2012b).

48. NPS reform should take into account the size of the National Pension Fund and the challenges of managing it. In addition to the principles of profitability and stability, the Fund is managed so as to "assure the public's benefit", notably through a positive impact on the nation's economy and financial markets. While the Fund's share of the domestic bond market fell from $23 \%$ in 2005 to $17 \%$ in 2012, its share of equities has doubled over that period to $5.4 \%$ of domestic stock markets, concentrated in large-cap stocks. The Fund has holdings of more than 5\% in around 250 companies, but is not allowed to hold more than $10 \%$ in order to limit public-sector influence on business enterprises through the exercise of voting rights. 
The Fund exercises its voting rights for its equity holdings with the purpose of increasing the value of its assets. During the first five months of 2012, for example, it cast 2329 votes, opposing the majority $7.6 \%$ of the time (NPS, 2012b). It is important to ensure a governance framework that prevents political influence on domestic companies in which the Fund invests. Boosting the share of foreign equities as planned (see below) would help overcome the size limitations in Korean markets.

49. The National Pension Fund thus faces the challenge of being a large asset holder in a small market, creating problems in fund management and the risk of a significant impact on domestic financial markets. One response to limit such risks has been increased globalisation of investment; the share of overseas equities and fixed-income assets rose from $9.4 \%$ in 2006 to $11.6 \%$ in 2012. Another response has been the increase in "alternative investments" - such as social infrastructure and real estate -- from $1.1 \%$ of the Fund in 2006 to $7.9 \%$ in 2012, with about one-half of it overseas.

50. The Fund has targeted a $6.3 \%$ rate of return by 2017. To achieve this, the share of domestic fixed-income assets is to be reduced to less than $60 \%$ of the Fund while the share of equities is to be increased to more than 30\% (20\% domestic and 10\% foreign) (Figure 14). In addition, the Fund will rely more on external management to raise returns while reducing the impact of the Fund's investment decisions on domestic financial markets (NPS, 2012b). The share of the Fund managed externally rose from $20 \%$ in 2009 to $29 \%$ in 2012 in an effort to increase returns and limit risks by decentralising investment decisionmaking. About one-half of externally-managed funds are in equities, with overseas equities accounting for $43 \%$ of that investment category.

\section{Improving the effectiveness of the NPS against elderly poverty}

51. The OECD recommends an overall replacement rate of around $70 \%$ through public and private schemes (Antolin, 2009). In Korea, however, the second and third pillars of the company system and individual pension saving accounts are estimated to have a combined replacement rate of only $20 \%$ for those who participate (Chung, 2010). Moreover, their coverage is low. In particular, the impact of the company pension system is limited by the fact that less than one-half of the working-age population are employees. Company pensions mainly cover regular workers, who account for less than one-third of the working-age population.

52. The NPS would need to achieve a replacement rate of around 50\%, therefore, to achieve the overall target of $70 \%$. However, the impact of the NPS will be limited by three factors. First, as noted above, only $43 \%$ of the working-age population contributed to the NPS in 2012 (Figure 8). Consequently, only $40.9 \%$ of the elderly in 2030 are expected to receive old-age pension benefits (Table 7). Second, the government projects that the average contribution period will be less than 20 years over 2030-40. Third, the replacement rate for a worker with 40 years of contributions and average earnings is to be lowered to $40 \%$, the sixth lowest in the OECD and well below the average of $54.4 \%$ (Figure 15 ). ${ }^{7}$ Given the short average contribution period, the replacement rate over 2030-40 would be less than $20 \%$. Not surprisingly, nearly one-half of those surveyed in 2012 expect that the NPS pension benefit will be insufficient to cover their basic living expenses when they are elderly (Seok et al., 2012).

53. Reaching the overall $70 \%$ target will likely require larger benefits from the NPS based on a threepronged approached. First, the share of the working-age population contributing to the NPS should be increased from its current level of $43 \%$. Second, the average contribution period should be lengthened to provide higher pension benefits. Third, the target replacement rate should be maintained around $50 \%$. Of course, such a higher replacement rate would require more revenue. If it were raised through contributions, the rate would have to rise to $16.7 \%$ to prevent a deficit in the NPS through 2083 .

7. On a net basis (i.e. after taxes), the targeted replacement rate is also the sixth lowest in the OECD at $45.2 \%$. 
Figure 15. An international comparison of pension replacement rates
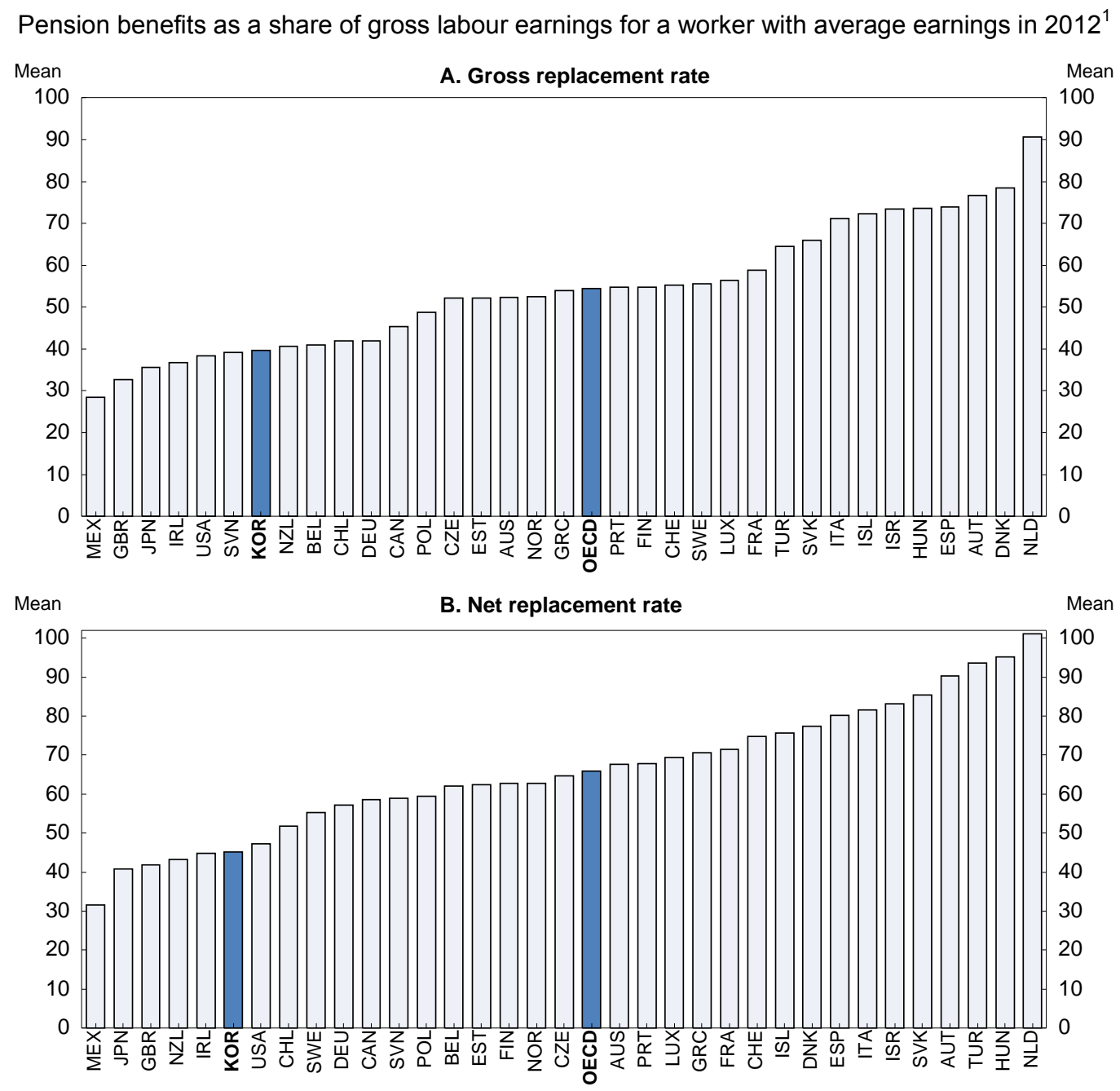

1. Includes public and mandatory private pensions.

Source: OECD (2013a).

54. Achieving the first two objectives of increasing the coverage of the NPS and lengthening the contribution period requires policies to increase the compliance of the self-employed and to enhance transparency about their income. Given the lack of transparency, the NPS assumes that the earnings of the self-employed match those of middle-income employees, thus discouraging low-income persons from contributing to the NPS as the burden is too heavy. While the National Tax Service is supposed to cooperate with the NPS, it appears to be reluctant to share information. Combining the collection of taxes and social contributions would improve transparency about the income of the self-employed.

55. Raising the share of non-regular workers who contribute to the NPS at their workplace from the current level of $38 \%$ is another priority. The low level reflects the preference of workers and firms to avoid the burdens of paying contributions, pointing to the need for better enforcement (Lee, 2012). In 2012, the government introduced a subsidy that pays one-half of the pension contribution for workers in small companies earning less than 1.3 million KRW per month (43\% of the average wage). However, this subsidy is estimated to have increased the number of contributors to the NPS by only 4 thousand. The government is considering extending the subsidy to the self-employed to further increase NPS coverage. 
ECO/WKP(2014)59

\section{Reforming the occupational pension schemes}

56. The occupational pension benefits were increased repeatedly under political pressures without corresponding financing measures, forcing them to rely increasingly on government subsidies. A 2009 reform aimed at enhancing the financial viability of the civil service pension scheme, which includes about $70 \%$ of the beneficiaries of the occupational pensions, by:

- Raising the contribution rate from 5.5\% of taxable wages to 7\% (compared to employee's share of $4.5 \%$ in the NPS).

- Reducing the accrual rate from $2.1 \%$ of career average gross earnings to $1.9 \%$ (compared to $1.0 \%$ in the NPS).

- Raising the minimum pension eligibility age to 65 for the newly insured (compared to 61 in the NPS).

Nevertheless, the outlook remains difficult as the number of retirees is increasing as the occupational pension schemes mature and pension coverage periods are becoming longer as life expectancy rises. Indeed, the number of pension beneficiaries is projected to increase from 29 per 100 insured workers in 2010 to 71 by 2030 (Kim and Moon, 2011). Unless action is taken, the schemes are likely to see a sharp rise in pension expenditures, boosting the deficit from $4.4 \%$ of the government's payroll in 2010 to $19.4 \%$ in 2030. The private-school teacher pension system went through a similar reform in 2009 that will reduce its financial deficits. However, much more needs to be done as the decline in the number of teachers in line with the falling number of children will aggravate the imbalances. As for the military pension, no reform has taken place (Chung, 2010).

57. A number of additional reforms are needed to limit the growing fiscal burden of the occupational pensions, particularly for civil servants. First, it is important to scale back the generosity of pension benefits, including the retirement allowance, which is $50 \%$ higher than for private-sector employees, reflecting differences in retirement age, the indexation method and the accrual rate. The high level of benefits, while NPS pensions have been reduced by one-third, has created equity problems between public and private-sector workers. Second, the government's contributions as an employer need to be expanded. While firms pay $12.8 \%$ of their payroll, $4.5 \%$ for the NPS and $8.3 \%$ for the retirement allowance or the company pension system, the burden for the government is only $7 \%$ even after the 2009 reform. Third, the 2009 reform created a sharp difference in the treatment of those already enrolled and those who joined the public service after 2009. The difference in the generosity of pension benefits may create intergenerational conflicts in the public service and make it difficult for the government to recruit and retain talented employees (Kim and Moon, 2011).

\section{Encouraging private-sector saving for retirement}

58. A financially sustainable and more generous NPS should be supplemented by greater private savings. It is thus important to accelerate the introduction of company pensions, which covered a quarter of employees at the end of 2012; at the current rate, it will take until 2019 to cover just one-half of all employees. It is important therefore to accelerate the shift away from the retirement allowance, given its weaknesses discussed above, and toward company pensions. In 2012, the government launched several measures to make the retirement allowance less attractive. First, the withdrawal of a worker's retirement allowance before leaving their company (including for retirement) is limited to specific purposes. Second, employees moving between jobs are required to place their retirement allowance in an Individual Retirement Pension (as is the case for company pensions). Third, the government has recently reduced the favourable personal income tax preferences that allow the retirement allowance to be taxed over a number 
of years at a low rate. It is important to assess the effectiveness of these measures in promoting the adoption of company pensions.

59. In 2012, the government required new firms to set up a company pension, based on preliminary consultations with employee representatives, without requiring a formal agreement with them, which has blocked the introduction of company pensions in some existing firms. The new provision should enable new enterprises to more easily set up a DC scheme, which is more convenient and less risky for them than a DB scheme. Allowing existing firms as well to set up company pension schemes based on preliminary consultations with their employees would accelerate the introduction of company pensions.

60. The third pillar of individual pension accounts, which remains underdeveloped in Korea, will also be essential to achieve an overall replacement rate of around $70 \%$. As noted above, one-half of investors terminate their plans within ten years. It is important to increase the penalties for early withdrawal of funds from the accounts to make them a more secure source of retirement income. In addition, more favourable treatment should be provided for existing contracts. Finally, increasing the range of choice in asset management may encourage the creation of individual accounts.

61. Given the importance of tangible assets, primarily real estate, which accounted for three-quarters of total household assets in Korea in 2012, reverse mortgages are an attractive option to deal with elderly poverty. In 2007, the government introduced reverse mortgages, called "housing pensions" in Korea, through the Korea Housing Finance Corporation $(\mathrm{KH})$, a public financial institution. Elderly homeowners take out loans that provide a monthly payment using their property as collateral. The loans are only repaid when the contract expires or the homeowner dies. Persons above the age of 60 who have one house and have paid off their mortgage are eligible for such mortgages. As in other countries, the idea of reverse mortgages has been slow to attract attention and the number remained small at 17595 at the end of 2013. Private financial institution's participation is limited due to the risk related to housing prices and less favourable tax treatment in the past (Choi, 2013). Given the importance of developing the market for reverse mortgages to reduce elderly poverty, the participation of private financial institutions should be encouraged. 
Box 1. Summary of recommendations to address poverty among the elderly in Korea

Immediate priorities to address poverty

- Target the Basic Old-Age Pension on the lowest-income elderly to ensure that all escape from absolute poverty ( $40 \%$ of national median income).

- Use the Basic Livelihood Security Programme to top up the income of the elderly in relatively poverty $(50 \%$ of national median income) by further relaxing eligibility requirements.

- Enhance the employability of older workers, in part by strengthening vocational training, to promote employment beyond the pension eligibility age.

- $\quad$ Raise the minimum mandatory retirement age set by firms with an aim of eventually abolishing mandatory retirement.

\section{Ensuring the sustainability and effectiveness of the National Pension Scheme and occupational pensions}

- Make the NPS more effective in reducing elderly poverty by expanding its coverage, focusing on improved compliance among non-regular and self-employed workers, lengthening average contribution periods and maintaining the NPS replacement at around 50\%, keeping it close to the OECD average.

- Begin as soon as possible to raise the NPS contribution rate to a level sufficient to ensure its long-run sustainability, thereby promoting confidence in the NPS and limiting the extent of the eventual hike in the contribution rate needed to achieve sustainability.

- Increase the return on the National Pension Fund by continuing the shift away from domestic bonds to equities and other investments, while expanding the share of overseas assets and boosting the share of the Fund managed externally.

- Combine the collection of taxes and social insurance premiums, including for the NPS, to enhance transparency about the income of the self-employed.

- Contain the deficits of the occupational pension schemes by bringing the generosity of pension benefits closer to that in the NPS and by increasing the government's contributions as employer.

\section{Encouraging private-sector saving for retirement}

- Accelerate the introduction of company pensions.

- Make Individual Pension Accounts a more important source of retirement income by measures to discourage their premature termination.

- Develop the market for reverse mortgages by encouraging the participation of private financial institutions. 


\section{Bibliography}

Antolin, P. (2009), "Private Pensions and the Financial Crisis: How to Ensure Adequate Retirement Income from DC Pension Plans", Financial Market Trends, OECD, Vol. 2009/2, OECD Publishing, Paris, http://dx.doi.org/10.1787/fmt-v2009-art22-en.

Beram, G. (2006), The Emergence of Occupational Pensions in Korea, mimeo.

Choi. S (2013), "Trend in Domestic Housing Pension Market and Implication", HANA Happiness Guide 2013 No. 02, HANA Institute of Finance, May 2013.

Chung, K. (2010), "Old-age Income Security System in Korea and Future Policy Issues", KIHASA Working Paper 2010-03, Korea Institute for Health and Social Affairs.

Feldstein, M. (1996), "Social Security and Saving, New Time Series Evidence", National Tax Journal, Vol. 49, No. 2.

Government of Korea (2013), Answers to OECD Questionnaire, mimeo, Seoul.

Joumard, I. and M. Pisu (2012), "Less Income Inequality and More Growth - Are they Compatible? Part 3. Income Redistribution via Taxes and Transfers across OECD countries", OECD Economics Department Working Papers, No. 926, OECD Publishing, Paris.

Kim, J. and H. Moon (2011), "Pension Systems for Public Sector Employees in the Republic of Korea", Institute of Economic Research, Hitotsubashi University, PIE-CIS Discussion Paper No. 499, Tokyo.

Kim, M. (2013), "Introduction of Retirement Pension System in Korea and its Current Situation", NLI Research Institute Report, March 2013, NLI Research Institute, Tokyo (in Japanese).

Kim, S. (2011), "Pension System and Women in Korea", International Social Security Research No. 175, National Institute of Population and Social Security Research, Tokyo (in Japanese).

Kim, S. (2013a), "Pension Reform Options in Korea”, IMF International Conference, Tokyo, January.

Kim, S. (2013b), "Providing Adequate Old-Age Pensions in Korea”, National Pension Research Institute, Seoul, mimeo.

Lee, C. and J. Lee (2011), "Employment Status, Quality of Matching, and Retirement in Korea", RAND Labor and Population Working Paper WR-834, RAND Corporation.

Lee, Y. (2012), "A Study on Old-Age Income Security Policy Measures to Cope with Population Aging and Income Polarization", Research Papers, National Pension Research Institute, Seoul.

Ministry of Health and Welfare (2013), The 2012 Basic Old-Age Pension from a Statistical Perspective, Seoul (in Korean).

Nam, C. (2013), "Restructure Pension Fund Governance", Capital Market Opinion, Korea Capital Market Institute, Seoul, 1 October.

National Pension Service (2012a), National Pension Statistical Yearbook, Seoul. 
National Pension Service (2012b), Working Together for a Better Tomorrow, Seoul.

National Pension Research Institute (2013), A Summary of the 2013 Actuarial Projection Result, March, Seoul.

OECD (2006), Ageing and Employment Policies, OECD Publishing, Paris.

OECD (2011a), Pensions at a Glance, OECD Publishing, Paris, http://dx.doi.org/10.1787/pension_glance2011-en.

OECD (2011b), Society at a Glance: Asia/Pacific 2011, OECD Publishing, Paris, http://dx.doi.org/10.1787/9789264106154-en.

OECD (2012), OECD Economic Survey of Korea 2012, OECD Publishing, Paris, http://dx.doi.org/10.1787/eco_surveys-kor-2012-en.

OECD (2013a), Pensions at a Glance, OECD Publishing, Paris, http://dx.doi.org/10.1787/pension_glance2013-en.

OECD (2013b), Strengthening Social Cohesion in Korea, OECD Publishing, Paris, http://dx.doi.org/10.1787/9789264188945-en.

OECD (2014), OECD Economic Survey of Korea 2014, OECD Publishing, Paris.

Seok, S., H. Kwon, H. Song, E. Lee, J. Oh, H. Shin and G. Kim (2012), "Middle- and Old-Aged Koreans' Preparation Realities for and Expectations about their Old Age", Research Papers, National Pension Research Institute, Seoul.

Statistics Korea (2010), Outcome of Social Survey 2010: Family, Education, Health, Security and Environment, Daejeon (in Korean).

Yoon, H. (2013), "Korea: Balancing Economic Growth and Social Protection for Older Adults", The Gerontologist, Vol. 53, No. 3.

Yun, S., I. Risku, K. Choi, Y. Chon, H. Shin, H. Yang, H. Lee and M. Kwon (2012), A Study on the Sustainable Contribution Level of the National Pension Scheme, Korea Institute of Health and Social Affairs, Seoul (in Korean).

Yun, S. (2013), "Current Status and Condition of Elderly Poverty and Income Distribution, and Direction of Income Support", Health and Welfare Forum, KIHASA, Seoul. 
$\mathrm{ECO} / \mathrm{WKP}(2014) 59$

\section{WORKING PAPERS}

The full series of Economics Department Working Papers can be consulted at www.oecd.org/eco/workingpapers

1162. Promoting the financing of SMEs and start-ups in Korea

(September 2014) by Randall S. Jones and Myungkyoo Kim

1161. Fostering inclusive growth by promoting structural change in the business sector.

(September 2014) by Rauf Gönenç, Oliver Röhn, Vincent Koen and Fethi Ögünç.

1160. Reducing macroeconomic imbalances in Turkey

(September 2014) by Oliver Röhn, Rauf Gönenç, Vincent Koen and Evren Erdoğan Coşar.

11xx The effect of the global financial crisis on the OECD potential Output

(September 2014) by Patrice Ollivaud and David Turner

1159. Reinvigorating the EU Single Market

(September 2014) by Jean-Marc Fournier.

1158. An exploration of the determinants of the subjective well-being of Americans during the great recession

(August 2014) by Aida Caldera Sánchez and Caroline Tassot.

1157. Boosting the development of efficient SMEs in the Netherlands

(September) by Rafał Kierzenkowski and Jochebed Kastaneer

1156. Making the banking sector more resilient and reducing household debt in the Netherlands (September 2014) by Rafał Kierzenkowski, Olena Havrylchyk and Pierre Beynet

1155. US long term interest rates and capital flows to emerging economies

(July 2014) by Eduardo Olaberria

1154. Productivity measurement with natural capital and bad outputs

(July 2014) by Nicola Brandt, Paul Schreyer and Vera Zipperer

1153. Reducing income inequality and poverty and promoting social mobility in Korea

(July 2014) by Randall S. Jones and Satoshi Urasawa

1152. Fostering a creative economy to drive Korean growth (July 2014) by Randall S. Jones and Myungkyoo Kim

1151. Economic uncertainties and their impact on activity in Greece compared with Ireland and Portugal

(July 2014) by Jan-David Schneider and Claude Giorno

1150. Workplace stress in the United States: issues and policies

(July 2014) by Michael Darden

1149. Taxing the rent of non-renewable resource sectors: a theoretical note

(July 2014) by Julien Daubanes and Saraly Andrade de Sá 
1148. Health, work and working conditions: a review of the European economic literature (July 2014) by Thomas Barnay

1147. Making the best of new energy resources in the United States (July 2014) by Douglas Sutherland

1146. Improving well-being in the United States (July 2014) by Aida Caldera Sánchez, Patrick Lenain and Sarah Fléche

1145. Deconstructing Canada's housing markets: finance, affordability and urban sprawl (July 2014) by Calista Cheung Restructurer les marchés canadiens du logement: financements, accessibilité financière et étalement urbain (Juillet 2014) par Calista Cheung

1144. Women's role in the Swiss economy

(July 2014) by Richard Dutu

Le rôle des femmes dans l'économie suisse

(Juillet 2014) par Richard Dutu

1143. Overcoming skills shortages in Canada

(July 2014) by David Carey

Combler les pénuries de compétences au Canada

(Juillet 2014) par David Carey

1142. Trade patterns in the 2060 world economy

(July 2014) by Jean Chateau, Lionel Fontagné, Jean Fouré, Åsa Johansson and Eduardo Olaberria

1141. The Demand for Skills 1995-2008: A global chain perspective

(July 2014) by Bart Los, Marcel P. Timmer and Gaaitzen J. De Vries

1140. International migration: The relationship with economic and policy factors in the home and destination country

(July 2014) by Ben Westmore

1139. Gross earning inequalities in OECD countries and major non-member economies: determinants and future scenarios

(July 2014) by Henrik Braconier and Jenifer Valenzuela Ruiz

1137. Managerial capital and business $R \& D$ as enablers of productivity convergence (September 2014) by Dan Andrews and Ben Westmore

1136. Long-term patterns of trade and specialisation

(July 2014) by Asa Johansson and Eduardo Olaberria

1135. Consequences of climate change damages for economic growth - a dynamic quantitative assessment

(July 2014) by Rob Dellink, Elisa Lanzi, Jean Chateau, Francesco Bosello, Ramiro Parrado and Kelly de Bruin 